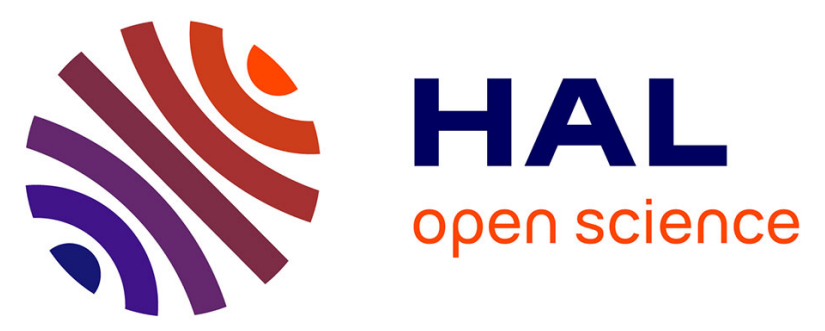

\title{
Five years update on relationships between malignant pleural mesothelioma and exposure to asbestos and other elongated mineral particles
}

Pascal Andujar, Aude Lacourt, Patrick Brochard, Jean-Claude Pairon, Marie-Claude Jaurand, Didier Jean

\section{To cite this version:}

Pascal Andujar, Aude Lacourt, Patrick Brochard, Jean-Claude Pairon, Marie-Claude Jaurand, et al.. Five years update on relationships between malignant pleural mesothelioma and exposure to asbestos and other elongated mineral particles. Journal of Toxicology and Environmental Health, Part B: Critical Reviews, 2016, 19 (5-6), pp.151-172. 10.1080/10937404.2016.1193361 . inserm-02478603

\section{HAL Id: inserm-02478603 https://www.hal.inserm.fr/inserm-02478603}

Submitted on 18 Feb 2020

HAL is a multi-disciplinary open access archive for the deposit and dissemination of scientific research documents, whether they are published or not. The documents may come from teaching and research institutions in France or abroad, or from public or private research centers.
L'archive ouverte pluridisciplinaire $\mathbf{H A L}$, est destinée au dépôt et à la diffusion de documents scientifiques de niveau recherche, publiés ou non, émanant des établissements d'enseignement et de recherche français ou étrangers, des laboratoires publics ou privés. 
Journal of Toxicology and Environmental Health, Part B

FIVE YEARS UPDATE ON RELATIONSHIPS BETWEEN MALIGNANT PLEURAL MESOTHELIOMA AND EXPOSURE TO ASBESTOS AND OTHER ELONGATED MINERAL PARTICLES

Pascal Andujar ${ }^{1-4}$, Aude Lacourt $^{5-6}$, Patrick Brochard ${ }^{6,7}$, Jean-Claude Pairon ${ }^{1-4}$, MarieClaude Jaurand ${ }^{8-11}$, Didier Jean ${ }^{8-11}$

${ }^{1}$ Institut Santé Travail Paris-Est, Université Paris-Est, Créteil, France

${ }^{2}$ CHI Créteil, Service de Pneumologie et Pathologie Professionnelle, DHU A-TVB, Créteil, France

${ }^{3}$ INSERM U955, Equipe 4, Créteil, France

${ }^{4}$ Universite Paris-Est Créteil, Faculté de Médecine, Créteil, France

${ }^{5}$ INSERM U1219, EPICENE, Bordeaux, France

${ }^{6}$ ISPED, Université de Bordeaux, Bordeaux, France

${ }^{7}$ CHU Bordeaux, Bordeaux, France

${ }^{8}$ INSERM, UMR-1162, Génomique fonctionnelle des tumeurs solides, Paris, France

${ }^{9}$ Université Paris Descartes, Labex Immuno-Oncology; Sorbonne Paris Cité, Paris, France

${ }^{10}$ Université Paris Diderot, IUH, Paris, France

${ }^{11}$ Université Paris 13, Sorbonne Paris Cité, Bobigny, France 


\section{ABSTRACT}

2 Despite the reduction of asbestos worldwide consumption and production due to the ban or 3 restriction of asbestos uses in more than 50 countries since the seventies, malignant 4 mesothelioma remains a disease of concern. Asbestos is still used, imported and exported in 5 several countries, and the number of mesothelioma deaths may be expected to increase in the 6 next decades in these countries. Asbestos exposure is the main risk factor for malignant pleural 7 mesothelioma, but other types of exposures are linked to the occurrence of this cancer. Although 8 recent treatments improve the quality of life of patients with mesothelioma, malignant pleural 9 mesothelioma remains an aggressive disease. Recent treatments have not resulted in appreciable 10 improvement in survival, and then the development of more efficient therapies is urgently 11 needed. The development of novel therapeutic strategies is dependent on our level of knowledge 12 of the physiopathological and molecular changes that mesothelial cells acquired during the 13 neoplastic process. During the past five years, new findings have been published on the etiology, 14 epidemiology, molecular changes and innovative treatments of malignant pleural mesothelioma. 15 This review aims to update the results of recent researches developed on the first three topics. It 16 will focus on the attributable risk of asbestos exposure in men and women, on co-exposure to 17 other minerals and other elongated mineral particles or high aspect ratio nanoparticles. Recent 18 data obtained on genomic and gene alterations, pathways deregulations, and predisposing factors 19 are summarized. 
3 After the early recognition of the occurrence of lung fibrosis and cancer in workers 4 occupationally exposed to asbestos fibers (Cooke 1924; Doll 1955; Sebastien et al. 1975;

5 Selikoff, Churg, and Hammond 1964; Simson 1928), and the discovery of the relationship to 6 malignant mesothelioma (Wagner, Sleggs, and Marchand 1960), numerous epidemiological and 7 experimental studies were developed to document the relationships between asbestos exposure 8 and human thoracic malignancies, such as lung cancer and malignant pleural mesothelioma. 9 However, from the middle/end of the $20^{\text {th }}$ century, research has shown that asbestos fibers are not 10 the only type of mineral elongated particles responsible for lung and pleural fibrosis and cancer, 11 in particular malignant mesothelioma. Human exposure to other natural mineral fibers has been 12 associated to malignant mesothelioma, such as erionite, fluoro-edenite, winchite, richterite and 13 tremolite (IARC 2012; Grosse et al. 2014; Dunning et al. 2012). Exposures to irradiation and 14 SV40 virus as co-factor have been also implicated in the development of malignant mesothelioma 15 (Chirieac et al. 2013; Farioli et al. 2013; Jasani and Gibbs 2012).

With the decrease in asbestos uses, some man-made mineral fibers have replaced these natural mineral fibers, especially mineral wool, glass fibers, and refractory ceramic fibers (RCFs), leading to the development of epidemiological studies in populations exposed to these fibers. IARC classified some man-made fibers (special-purpose fibers and RCFs) as carcinogenic in experimental animals, but lacking of epidemiological data; these fibers were classified in the $2 \mathrm{~B}$ group, as possibly carcinogenic to humans. These researches were situated in the landscape of investigations developed to understand the health effects resulting from exposure to asbestos fibers and other elongated mineral particles (EMPs) (NIOSH 2011). More recently, with the development of nanotechnologies, including carbon nanotubes, the historical of asbestos diseases allowed to propose that high aspect ratio nanoparticles (HARNs) have a special cancer potential to the lungs and mesothelium, and to develop a paradigm for hazard assessment (Aschberger et al. 2010; Donaldson and Poland 2012; Tran et al. 2011).

The question of co-exposure is an important challenge to identify and define risk factors. In occupational situations, workers previously exposed to asbestos may have been exposed to 
1 replacement fibers, and the potential effects of co-exposures also need to be investigated.

2 Otherwise, to anticipate further issues related to exposure to other EMPs and HARNs, a better

3 knowledge of the mechanism of action and biological signature of fibers, other EMPs and

4 HARNs is needed for regulation and prevention purposes (NIOSH 2011). Moreover, co-

5 exposures to asbestos and silica are also of interest as silica is not known to induce mesothelioma,

6 but joint effects might modify the incidence.

8 Mesothelioma arises from the neoplastic transformation of mesothelial cells. For studying the 9 carcinogenic effects of fibers, mesothelioma represents a specific disease, due to its relationship 10 with exposure to mineral fibers. Mesothelioma is linked to past-asbestos exposure in about $80 \%$ 11 of the cases. Investigation of physio-pathological changes in mesothelioma, including genomic 12 changes, is of particular interest to link the alterations to the mechanism of action of the fibers. 13 Other extra-thoracic cancers are associated to asbestos exposure, but the link is weaker. A link 14 between asbestos exposure and ovarian cancer is clearly established, based on the study of 15 several strongly positive cohort mortality studies of women with heavy occupational exposure to 16 asbestos, and on a meta-analysis (Bunderson-Schelvan et al. 2011; Camargo et al. 2011; IARC 17 2012; Reid et al. 2013). Moreover, a causal association between asbestos exposure and laryngeal 18 cancer has been also established (IARC 2012; Menvielle et al. 2016; Offermans, Vermeulen, 19 Burdorf, Goldbohm, Kauppinen, et al. 2014). Recently, an association between occupational 20 asbestos exposure and pharyngeal squamous cell carcinoma in men has been also reported 21 (Langevin et al. 2013). Finally, since the last revaluation of asbestos related cancers by IARC in 22 2012, associations between asbestos exposure and digestive cancers have been reported. Indeed, 23 significant links between mortality due to stomach cancer or oesophagus cancer have been well 24 documented (Offermans, Vermeulen, Burdorf, Goldbohm, Keszei, et al. 2014). For stomach 25 cancer, a meta-analysis reported a meta-Standardized Mortality Ratio (SMR) $=1.15$ [95\% 26 Confidence Interval (CI): 1.03-1.27] and for oesophagus cancer, the meta-SMR was 1.24 [95\% 27 CI: 1.13-1.38], with little evidences of heterogeneity (Fortunato and Rushton 2015; Li, Tang, and 28 Wang 2015). Likewise, the role of asbestos exposure in colorectal cancers remains controversial 29 (Bunderson-Schelvan et al. 2011; Clin et al. 2011; Fang, Le, and Band 2011; IARC 2012). A 30 suggestive relationship for colon cancer incidence was recently found, but with less conclusive 31 results for rectal cancer (Offermans, Vermeulen, Burdorf, Goldbohm, Keszei, et al. 2014). 
2 Despite the decrease in asbestos production, and asbestos ban in several countries, mesothelioma 3 remains a disease of concern, because of the particularly long latency period between the time 4 since first exposure to asbestos and the onset of the disease with an average of 40 years (30-50 5 years) (Robinson, Musk, and Lake 2005; Rolland et al. 2010). The World Health Organization 6 (WHO) has estimated that mesothelioma, lung cancer, and asbestosis are responsible for about 7 107,000 deaths worldwide (Delgermaa et al. 2011; Kameda et al. 2014; Stayner, Welch, and 8 Lemen 2013). Bang et al. estimated that the importance of premature mortality and loss of 9 potentially productive years of life attributable to asbestos-related diseases were very stable 10 between 1999 and 2010 in United States (Bang et al. 2014). This finding underlies the importance 11 to maintain prevention efforts and to monitor surveillance of asbestos-related diseases temporal 12 trends (Bang et al. 2014). Moreover, the outcome of patients with MPM is poor, long-term 13 survival is rare, with the majority of patients succumbing to their disease within 2 years of 14 diagnosis(Davidson 2015). An increase of only 3 months in overall survival with anti-VEGF and 15 anti-folate therapy has been reported (Zalcman et al. 2015). A strong development of researches 16 to prevent and treat this cancer is needed. In recent years, efforts have been made to improve 17 diagnosis and prognosis, and to design treatments more adapted to the morphological and 18 biological characteristics of the tumors (Musk et al. 2011; Robinson, Musk, and Lake 2005).

19 So far, the histological diagnosis of mesothelioma remains based on 3 predominant subtypes: 20 epithelioid (50 to 60\%), sarcomatoid (10 to 20\%), biphasic corresponding comprising epithelioid 21 and sarcomatoid components (25 to $35 \%$ ) and a smaller percentage of desmoplastic forms (1 to 22 2\%) (Husain et al. 2013). Well-differentiated papillary mesothelioma is an uncommon form of 23 epithelioid mesothelioma, that is generally a non-invasive tumor with low malignant potential 24 and that occurs mostly in women in the peritoneum, but also in pleura, pericardium, and tunica 25 vaginalis. Some rare cases of well-differentiated papillary mesothelioma with invasive foci are 26 now recognized as stressed in several publications (Churg et al. 2014; Galateau-Salle et al. 2004).

27 Recent biological studies of cancers allow the identification of biomarkers, and benefit of high 28 throughput cell biology technologies, so-called "omics researches", that permit to characterize the 29 genetic, metabolic and physiological changes linked to cancer. In this area of researches, new 30 findings have been recently reported on mesothelioma. 
1 The aim of the present work was to summarize the literature data published during the last five 2 years, focusing on epidemiology of malignant pleural mesothelioma (MPM), with special interest 3 to data on co-exposure to asbestos and other fibers, and to silica. Recent advances in our 4 knowledge on the biology of mesothelioma will be summarized. They concern the genetic and 5 epigenetic alterations of the tumor, and possible links to asbestos, and their impact in the 6 treatment of mesothelioma. At the cell level, some new data are related to the deregulation of 7 signaling pathways, and stemness-related features of tumor cells. 
1 HUMAN EXPOSURE TO ASBESTOS AND OTHER EMPs AND MALIGNANT 2 MESOTHELIOMA

4 In this review, asbestos refers to the natural minerals that are considered in industries and used in

5 experimental-related studies devoted to the investigation of the pathological effects of asbestos.

6 Asbestos is the commercial name given to a family of natural silicate mineral fibers; it refers to

7 the 6 commercial types of asbestos (two varieties: feathery serpentines (chrysotile), and long and

8 thin fibers of amphiboles (crocidolite, amosite, anthophyllite, tremolite and actinolite)) (Case et

9 al. 2011). According to WHO methodology, fibers are defined as particles thinner than $3 \mu \mathrm{m}$,

10 longer than $5 \mu \mathrm{m}$ and of aspect-ratio $>3$. An EMP is an elongated mineral particle thinner than

$113 \mu \mathrm{m}$, longer than $5 \mu \mathrm{m}$ and of aspect-ratio $>3$, independently of its chemistry. Then asbestos

12 fibers are also EMP. Other non-asbestiform, non-commercial amphiboles, as found in the

13 vermiculite mines in Libby, such as winchite, richterite and tremolite, are EMP as far as their

14 dimensions correspond to the definition. There is evidence to support the association between

15 exposure to these fibers and the occurrence of asbestos-related diseases, especially nonmalignant

16 pleural abnormalities, lung cancer, and malignant mesothelioma (Antao, Larson, and Horton

17 2012; Carlin et al. 2015).

Recent epidemiological advances linked to asbestos exposure

21 Mesothelioma is mainly attributable to occupational or environmental asbestos exposure. All 22 forms of asbestos fibers are carcinogenic to human, and both pleural and peritoneal 23 mesotheliomas are associated with asbestos exposure (IARC 2012). Despite ban of asbestos in 24 some countries, and decline of worldwide production and use of asbestos, these minerals still 25 represent a health problem (Stayner, Welch, and Lemen 2013). Asbestos consumption is 26 increasing in other parts of the world such as India and much of Asia. Since recent publications

27 have reviewed epidemiological data on asbestos exposure, we did not make a 28 comprehensive review of the relevant literature, but instead summarized the main findings 29 reported in these reviews. Briefly, in a worldwide literature review, all types of asbestos fibers 30 were found to cause mesothelioma, including chrysotile (Kanarek 2011). Another review 31 examining the patterns of asbestos exposure (production, export and use) and of asbestos-related 
1 diseases concluded that all forms of asbestos fibers are carcinogenic to humans (Frank and Joshi

2 2014). The potency of the different fiber types for lung cancer risk was recently discussed, and

3 authors have questioned the already reported and accepted potency factors for asbestos-related

4 lung cancer, suggesting that differences might be lower (van der Bij et al. 2013). Toxicological

5 and epidemiological studies on effects of airborne fibers were also considered for risk assessment

6 (Lippmann 2014). This author concluded that the effects are dependent on fiber diameter, length,

7 and biopersistence; biopersistent fibers, thinner than $0.1 \mu \mathrm{m}$ and longer than $5 \mu \mathrm{m}$ being the most

8 relevant for mesothelioma (Lippmann 2014). Nevertheless, in an exhaustive review focusing on

9 available information from peer-review publications on the size-dependent pathogenic effects of

10 asbestos fibers reported in experimental in vivo and in vitro studies, fibers shorter than $5 \mu \mathrm{m}$ were

11 less pathogenic than fibers longer than $5 \mu \mathrm{m}$, but the cut-off of $5 \mu \mathrm{m}$ as the limit for length is

12 used for metrological analyses using light microscopy and is not based on scientific evidence

13 (Boulanger et al. 2014)

Occupational exposure to asbestos

17 Because of their specific chemical and physical properties asbestos fibers have been used in a

18 variety of building construction materials and in a wide range of manufactured goods (IARC

19 2012). Early investigations on asbestos health effects concerned workers in the production and

20 handling of asbestos products. Over the last decades, a shift has been observed in the exposure

21 history of MPM cases, from primary asbestos workers (handling raw asbestos material) to end-

22 users often exposed when installing asbestos products or handling asbestos materials that are still

23 in place (Scherpereel et al. 2010). Elevated risks of MPM were found in sheet-metal workers,

24 plumbers, metal molders, welders, core-makers, cabinetmakers and firefighters, and in the

25 industries of construction, shipbuilding, manufacturing of metal products, chemicals, and railroad

26 and aircraft equipment (Pukkala et al. 2014; Rolland et al. 2010).

27 An English case-control study estimates lifetime risks for British-born male in the 1940s with $28 \geq 10$ years of asbestos exposure before the age of 30 years-old. Lifetime risks were estimated at $295.9 \%$ for carpenters, $2 \%$ for electricians, plumbers and painters, $0.8 \%$ for other construction 30 workers, $1.8 \%$ for other recognized high-risk occupations and $0.6 \%$ in other industries where 31 asbestos may be encountered (Rake et al. 2009). Otherwise, a British cohort study did not find 
1 sufficient evidence that greater intensity asbestos exposures would lead to shorter mesothelioma

2 latencies (Frost 2013).

\section{Environmental exposure to asbestos}

6 MPM is also linked to environmental exposure to asbestos, either in areas of the world where asbestos (generally tremolite) exists as a geological component of the soil (Corsica in France,

8 Cyprus, Turkey, and New Caledonia) or to neighborhood exposures in people living close to 9 asbestos mines or factories, such as the residents of Wittenoom, an Australian town near a crocidolite mine, or in Casale Monferrato, an Italian town next to an asbestos cement factory

11 (Baumann et al. 2011; Ferrante et al. 2015; Hillerdal 1999). Residential distances from industrial 12 sources of asbestos and wind conditions have an impact on the risk of developing environmental 13 mesothelioma (Kurumatani and Kumagai 2008; Tarres et al. 2013). Domestic cases are described 14 in households of asbestos workers, mainly because of asbestos exposure via clothes used at work 15 and washed at home (Lacourt et al. 2014).

Few studies estimated the attributable risk (AR) of asbestos exposure for MPM (Agudo et al. 2000; Aguilar-Madrid et al. 2010; Lacourt et al. 2014; Rake et al. 2009; Spirtas et al. 1994).

21 While for men, AR of occupational asbestos exposure ranged from 83.1\% [99\% IC: 74.5-91.5] in 22 France to $85 \%$ in the United Kingdom (Lacourt et al. 2014; Rake et al. 2009), it was 23 systematically lower in women from 22.5\% [95\% CI: 3.2-71.7] in the United States to $41.7 \%$ 24 [99\% CI: 25.3-58.0] in France (Lacourt et al. 2014; Spirtas et al. 1994). Two studies estimated an 25 AR of occupational asbestos exposure without stratifying by sex; it was 62.0\% [99\% CI: 48.426 75.6] including all probabilities of exposure to asbestos in Spain and 44\% in Mexico (Agudo et 27 al. 2000; Aguilar-Madrid et al. 2010).

28 Besides occupational asbestos exposure, the French and UK studies estimated the AR of nonoccupational asbestos exposure among subjects never occupationally exposed to asbestos. A difference between men and women still persisted, but the AR was higher in women than in men:

31 in France, the AR among men was 20.0\% [99\% CI: 33.5-73.5] against 38.7\% [99\% CI: 8.4-69.0] 
1 in women and in United Kingdom, the AR among men was 1.3\% against $16 \%$ in women (Rake et 2 al. 2009). In total, from $86.4 \%$ to $87.3 \%$ of male cases and from $38.1 \%$ to $64.8 \%$ of female cases 3 were attributed to any source of asbestos exposure (Lacourt et al. 2014; Rake et al. 2009). Thus, 4 these recent data highlight that in women, the AR of asbestos exposure for MPM is enhanced 5 when considering only occupational exposure to asbestos, in comparison with both occupational 6 and non-occupational exposures (38.1\% vs 64.8\%), whereas this AR remains relatively stable in 7 men (86.4\% and 87.3\%, respectively) (Lacourt et al. 2014). Nevertheless, an unexplained part of

8 AR for MPM in women (about a third) still persists due to weak asbestos exposure, very remote 9 in time of exposure or other still unknown etiological factors.

10 In an exhaustive study of 318 female MPM cases in the French National Mesothelioma

11 Surveillance Program between 1998 and 2009, 4 clusters were identified: occupational exposure 12 to asbestos and man-made vitreous fibers (MMVF) (7.9\%); radiation exposure during 13 radiotherapy (12.9\%); any asbestos exposure (19.8\%); and "non-exposure" characteristics 14 (59.4\%) (Camiade et al. 2013).

\section{Co-exposures to asbestos and MMVF or silica particles}

18 This part of the review of the literature focuses on the joint effect of asbestos and other EMPs, 19 namely, MMVF. Workers previously exposed to asbestos may have been further exposed to other 20 particles. The question of co-exposure is an important challenge to identify and define risk

21 factors. Co-exposures to asbestos replacement fibers are emerging. Co-exposures to silica are 22 also of interest as silica is not known to induce MM but joint effects might modify the incidence 23 of MPM. Then, these associations are also considered here. From cohort studies of workers, the 24 joint effect of asbestos and other particles has not been studied likely due to the small number of 25 observed mesothelioma cases and the availability of exposure data for both asbestos and other 26 mineral particles.

27 From case-control studies, only 3 population-based studies (Germany, Canada and France) 28 attempted to study the joint effect of occupational asbestos exposure and other mineral particles 29 (Lacourt et al. 2013; Lacourt et al. 2014; Pintos et al. 2009; Rodelsperger et al. 2001). In the three 30 studies, all cases were incident and histologically confirmed male cases. Whereas occupational 
1 asbestos exposure and MMVF exposure were retrospectively assessed by expertise in the German

2 and Canadian study, job-exposure matrices were used in the French study.

3 The German study included 125 cases and 125 controls recruited from Hamburg between 1988

4 and 1991 (Rodelsperger et al. 2001). Whereas odds ratios (ORs) for subjects only exposed to

5 asbestos and for subjects only exposed to MMVF were 19.8 [95\% CI: 4.7-83] and 15.1 [95\% CI:

6 1.05-218], respectively, OR increased by a factor of four when subjects were exposed to both 7 asbestos and MMVF (OR=61.3 [95\% CI: 12.9-292]). The Canadian study included 35 cases and

81,965 control subjects recruited from Montreal between 1979 to 1986 or 1996 to 2001 (Pintos et

9 al. 2009). OR was increased for subjects ever exposed to both asbestos and MMVF (OR=8.0

10 [95\% CI: 3.4-18.9]) compared to those only exposed to asbestos (OR=1.2 [95\% CI: 0.3-4.3]).

11 While both studies reported a potential synergistic joint effect of asbestos and MMVF, it should

12 be noted that $95 \%$ CI were wide and overlapped each other. Besides, the joint effect of asbestos

13 and MMVF was studied using an ever vs never exposed indicator for both exposures. Thus, the

14 increased OR observed for subjects exposed to both asbestos and MMVF may be due to

15 confounding by asbestos exposure. The cumulative asbestos exposure may be higher in subjects

16 exposed to both asbestos and MMVF compared to subjects only exposed to asbestos leading to an

17 artificially increased OR. In the Canadian study, authors further adjusted for the duration of

18 asbestos exposure in their models but results were unchanged.

19 To account for confounding by asbestos exposure, the French study conducted analysis looking at

20 the dose response relationship between occupational asbestos exposure and MPM in the presence

21 or absence of additional exposure to mineral wool, crystalline silica or refractory ceramic fibers

22 (Lacourt et al. 2013; Lacourt et al. 2014). This study included 1,199 cases and 2,379 controls

23 recruited from several districts of France between 1987-1996 and 1998-2006. Authors

24 systematically reported that the effect of occupational asbestos exposure was increased in

25 presence of a co-exposure. When considering the entire dataset, for subjects occupationally

26 exposed only to asbestos between 1 to 10 fibers/ml.yrs, the OR was 3.7 [95\% CI: 2.4-5.6]

27 compared to subjects not exposed to asbestos, mineral wool and silica. However, it increased to

287.1 [95\% CI: 5.0-10.1], 8.9 [95\% CI: 4.5-17.6] and 10.3 [95\% CI: 7.0-15.0] when subjects were

29 additionally exposed to mineral wool, silica or to the three mineral particles respectively

30 (Lacourt et al. 2013). When restricting the dataset to subjects ever exposed to asbestos (988 cases

31 and 1,125 controls), the OR for subjects occupationally exposed only to asbestos at 50 fibers/ml- 
yrs was 1.9 [95\% CI: 1.4-2.5] and was 12.8 [95\% CI: 4.7-35.1] when subjects were additionally exposed to refractory ceramic fibers (Lacourt et al. 2014). While the issue of the joint effect of asbestos and other mineral particles should be further explored, from the actual literature, the hypothesis of a synergistic joint effect should be considered.

(1)

(1)

\section{Association between pleural plaques and MPM or lung cancer}

Pleural plaques are benign fibrotic lesions thickening parietal or diaphragmatic pleura, composed of avascular and acellular collagen connective tissue. Pleural plaques are mostly linked to past asbestos exposure. Recently, a follow-up study from the French Asbestos-Related Diseases Cohort (ARDCO), based on a screening Program for Asbestos-Related Diseases in asbestosexposed male subjects $(n=5,287)$, reported a strong association between the occurrence of MPM and pleural plaques detected by CT scan (unadjusted hazard ratio (HR) $=8.9$ [95\% CI: 3.0-26.5]; adjusted HR $=6.8[95 \%$ CI: 2.2-21.4] after adjustment for time since first exposure and cumulative exposure index to asbestos). The results of this study suggest that pleural plaques are an independent risk factor of MPM (Pairon et al. 2013). More recently, a significant association between pleural plaques and lung cancer mortality was reported after adjustment for smoking status and asbestos exposure in this same cohort among 1,118 subjects $(20.7 \%)$ with pleural plaques after 6-year follow-up (Pairon et al. 2014).

\section{Human exposure to other EMPs and MPM}

\section{Amphiboles, other than asbestos}

Asbestos is not the only EMP associated to an enhanced risk of mesothelioma development. Other amphiboles (winchite and richterite, so-called "Libby amphiboles") found in vermiculite mines in Montana (USA) induce mesothelioma in human, and show biological actions, in animals and cultured cells, similar to asbestos fibers (Cyphert et al. 2012; Dunning et al. 2012; Hillegass et al. 2013; Kodavanti et al. 2014). In a recent publication, an elevated percentage of mesothelioma in women, and individuals younger than 55 years, was reported in Southern Nevada, as due to environmental exposure to amphiboles (Baumann, Buck, et al. 2015). In these areas, several types of amphiboles were found, as in Libby (winchite, richterite and tremolite), as 
1 well as actinolite) (Baumann, Buck, et al. 2015). Elsewhere, an excess of mesothelioma has been

2 observed in iron ore miners in Northeastern Minnesota, where mining and processing of taconite 3 iron ore generate non-asbestos EMP of undefined type (Lambert et al 2016). Fluoro-edenite is an

4 endemic natural amphibole fiber present in Biancavilla soil in Sicilia (Italy) and also present in

5 the major quarry from which building materials have been extensively extracted. The risk

6 estimated of incidence of MPM in Biancavilla town is higher than in the Sicilian region (Biggeri

7 et al. 2004; Bruno et al. 2014; Comba, Gianfagna, and Paoletti 2003). Recently, a probable link

8 between the presence of pleural plaques and exposure to fluoro-edenite fibers in subjects not

9 exposed to asbestos has been reported through residing in Biancavilla and through their

10 occupation (Rapisarda et al. 2015). IARC classified fibrous amphibole fluoro-edenite as

11 carcinogenic to humans (Group 1) (Grosse et al. 2014).

Erionite

15 Erionite belongs to another group of natural minerals, the zeolite group. It is endemic in Turkey 16 and western United States, also strongly associated with the risk of development of mesothelioma

17 (Carbone et al. 2011; Jasani and Gibbs 2012). Recently, erionite has been also localized in 18 Central Mexico and associated to a high risk of mesothelioma and lung cancer (Ortega-Guerrero 19 et al. 2015).

\section{Synthetic vitreous fibers}

23 Synthetic vitreous fibers (SVF) are subdivided into glass wool, rock wool, slag wool, refractory 24 ceramic fibers and other special-purpose fibers. The IARC classification of SVF was based on 25 chronic inhalation and intra-tracheal instillation studies of special-purpose glass fibers resulted in 26 significant increases of MPM in rats and hamsters. Insulation glass wool, continuous glass 27 filament, rock (stone) wool and slag wool are not classifiable as to their carcinogenicity to 28 humans (Group 3) (IARC 2002). Recently, the existence of little epidemiologic and toxicological 29 evidence concerning a potential link between SVF exposure and risk of mesothelioma occurrence 30 was reported (Boffetta et al. 2014). RCFs have a carcinogenic potency in animals, causing lung 31 cancer and mesothelioma (IARC 2002). In epidemiological studies, a significant association has 
1 been previously reported, with the occurrence of pleural plaques detected on chest X-ray, but no

2 significant link was established between MPM and RCF exposure in humans (Lockey et al. 1996;

3 Lockey et al. 2002). According to our knowledge, no new epidemiological data is available.

4 Presently, the link between respiratory cancers occurrence and SVF exposure is still unclear, but

5 some fibers may have characteristics able to induce pathogenic effects (Greim et al. 2014;

6 Lippmann 2014).

\section{Other elongated nanoparticles (Carbon nanotubes, carbon nanofibers, tubular clays)}

10 The health effects of other types of HARNs, carbon nanotubes (CNTs), carbon nanofibers

11 (CNFs) and nanotubular clays are a present subject of researches (Genaidy et al. 2009; Jaurand

12 2015; Kayat et al. 2011; Lecouvet 2015). Numerous studies were recently performed to

13 investigate the health effects of CNTs. CNTs are new technological material receiving a large

14 range of industrial and biomedical applications due to their particular electronic and mechanical

15 properties (Kayat et al. 2011; Aschberger et al. 2010; Shvedova et al. 2009; Tran, Zhang, and

16 Webster 2009; Upadhyayula et al. 2009). Industrial and economic development of

17 nanotechnology requires the political and scientific communities to consider issues relating to

18 safety of these materials (Fatkhutdinova, Khaliullin, and Shvedova 2015; Jaurand and Jean 2016).

19 CNTs belong to the category of HARNs, with diameters less than or equal to 100 nanometers, 20 and length that may reach several dozen of micrometers. There are several classes of CNTs,

21 single-walled, double-walled and multi-walled carbon nanotubes. The main route of human

22 occupational exposure is suggested to be inhalation and dermal contact, but environmental

23 exposure could occur regarding the uses of CNTs (Aschberger et al. 2010; Tran, Zhang, and

24 Webster 2009). The ecotoxicological impact of CNTs is also of concern (Upadhyayula et al.

25 2009). Presently, there is no epidemiological data on the effects of CNTs on human health.

26 Experimental studies are available, showing that some CNTs may have biological effects similar

27 to asbestos (cellular damage, pulmonary inflammation, genotoxicity) (Genaidy et al. 2009;

28 Jaurand 2015; Kayat et al. 2011). A recent IARC monograph reviewed the literature on the

29 toxicological effects of CNTs. One type of multi-walled CNTs (MWCNT-7) was classified as

30 possibly carcinogenic to humans (Group $2 \mathrm{~B}$ ), and single-walled CNTs and multi-walled CNTs 
1 excluding MWCNT-7 as not classifiable as to their carcinogenicity to humans (Group 3) (Grosse

2 et al. 2014).

3 Other naturally occurring minerals of nanotubular structure, such as the natural clay minerals,

4 halloysite and imogolite, are used in many industrial applications (Vahedi and Pasbakhsh 2015).

5 Halloysite forms multi-layered hollow cylinders and imogolite forms single walled tubes.

6 Halloysite has been used commercially in ceramics and potteries, and as reinforcing agents. Due

7 to their properties, these aluminosilicate nanotubes have potential applications in catalysis,

8 molecular separation, and as loading agents in polymers. Both have potential applications in the

9 area of drug delivery systems and nanobiomedicine (Abdullayev and Lvov 2011; Rapisarda et al.

10 2015). They can be used as unmodified or surface-modified depending on their uses. A few

11 studies have investigated the toxicity of naturally occurring clays. So far, halloysite nanotubes do

12 not appear to exert a cytotoxic effect while some imogolite nanotubes may be cytotoxic and

13 genotoxic. However, due to the insufficient number of studies and wide diversity of the

14 nanotubes it is not possible to draw conclusions on their potential impact on human health

15 (Jaurand In press; Maisanaba et al. 2015).

RECENT ADVANCES IN OUR KNOWLEDGE ON THE MOLECULAR BIOLOGY OF 18 MALIGNANT MESOTHELIOMA

\section{Genomic alterations in MPM}

21 The genes with the highest frequency of genetic alteration in MPM are CDKN2A (cyclin22 dependent kinase 2A), NF2 (neurofibromin type 2) and BAP1 (BRCA1 (breast cancer 1)23 associated protein 1) tumor suppressor genes (COSMIC v2,

24 http://cancer.sanger.ac.uk/cosmic) (Forbes et al. 2015).

25 The first two are known for a long time, but recurrent somatic mutations in BAPl gene were 26 more recently identified (Bott et al. 2011). BAP1 is a tumor suppressor gene located on $3 \mathrm{p} 21$, a 27 chromosome region frequently lost in mesothelioma (Jean et al. 2012). The percentage of BAPI 28 mutations in sporadic MPM reported in the literature depended on the method of analysis; most 29 of sequencing methods did not allow detection of large deletion in tumor samples due to the 30 presence of normal contaminated cells. The percentage of mutations in tumor samples was 20 $3123 \%$, as determined by Sanger sequencing (Testa et al. 2011; Zauderer et al. 2013). Bott et al. 
1 found $42 \%$ BAP1 loss or mutation in primary mesothelioma by integrated genomic analysis and

2 FISH (Fluorescence In Situ Hybridization) (Bott et al. 2011). Higher rate (61\%) was reported in

3 DNA isolated from cultures of mesothelioma tumors, in a Japanese study using Sanger

4 sequencing, array CGH (Comparative Genomic Hybridization) and real-time polymerase chain

5 reaction (PCR) (Yoshikawa et al. 2012). A similar rate was reported in 22 frozen biopsies of US

6 patients (Nasu et al. 2015). Sanger sequencing detected mutations in DNA in 27\% of the cases

7 and a total of $60 \%$ was found with further MLPA analysis (Multiplex Ligation-dependent Probe

8 Amplification). These results point out that an integrated approach is required to determine the

9 frequency of $B A P 1$ genetic alterations in mesothelioma.

10 Inactivation of $C D K N 2 A, N F 2$ or $B A P 1$ genes in mice enhance the frequency of mesothelioma

11 after exposure to asbestos, showing that they are driver genes of mesothelial carcinogenesis

12 (Altomare et al. 2011; Fleury-Feith et al. 2003; Xu et al. 2014). CDKN2A gene encodes two cell

13 cycle regulators $\mathrm{p} 16^{\mathrm{INK} 4 \mathrm{~A}}$ and $\mathrm{p} 14^{\mathrm{ARF}}$. This gene is located on a locus in $9 \mathrm{p} 21$, frequently lost by

14 homozygous deletion in MPM, which also contains the $C D K N 2 B$ gene explaining also the

15 frequent alterations to this later gene (Jean et al. 2011). NF2 gene encodes the merlin

16 multifunctional protein that plays a role in cell adhesion and regulates many signaling pathways

17 involved in cell proliferation including Hippo pathway. BAPI gene encodes a nuclear

18 deubiquitinase particularly involved in transcription regulation and remodeling of chromatin

19 whose functions are not fully known. Other tumor suppressor genes are mutated at lower

20 frequencies in MPM as the well-known TP53 gene involved in the carcinogenesis of several

21 cancers (COSMIC v2) (Forbes et al. 2015) or the LATS2 gene (Bott et al. 2011; Murakami et al.

22 2011). LATS2 gene encodes a serine-threonine kinase that is a member of the Hippo pathway as

23 merlin (NF2). Members of other signaling pathways have mutation in MPM, such as the

24 hedgehog pathway, but at a lower frequency than Hippo pathway (Lim et al. 2013).

25 In contrast to tumor suppressor genes, oncogene mutations are infrequent in MPM. Mutations in

$26 K R A S, B R A F, E G F R$ and PIK3CA genes have been described earlier in the literature and the low

27 frequency rate of mutation was confirmed by recent studies (Mezzapelle et al. 2013; Schildgen et

28 al. 2015; Shukuya et al. 2014). Oncogenic recurrent mutations in the TERT promoter were also

29 identified at a low frequency, but are strongly associated with sarcomatoid MPM. These

30 mutations are involved in the overexpression of the gene encoding the catalytic subunit of

31 telomerase (Tallet et al. 2014). 
1 There are only few NGS (Next Generation Sequencing) data for MPM. Recently, the CUL1 gene,

2 a component of an ubiquitin ligase, was suggested as a driver gene for mesothelial

3 carcinogenesis, as the frequency of damaging CUL1 mutations was greater than the significance

4 threshold expected for driver mutations in an exome sequencing study of 22 MPM (Guo et al.

5 2015). Genetic alterations of member genes of the mSWI/SNF chromatin remodeling complex

6 and of the Hippo pathway, others than NF2 and LATS2 genes, were found in another NGS studies

7 of 8 and 16 MPM, respectively (Miyanaga et al. 2015; Yoshikawa et al. 2012). The largest NGS

8 study including 123 formalin-fixed, paraffin-embedded (FFPE) biopsies showed a complex

9 landscape view of the somatic genomic alterations in MPM (Lo Iacono et al. 2015). The pattern

10 of MPM mutation would be clarified with the expected release of TCGA (The Cancer Genome

11 Atlas, https://tcga-data.nci.nih.gov) exome data, which included 87 MPM.

\section{Genomics of MPM}

15 Several omics studies have been conducted on MPM to identify chromosomal alterations,

16 epigenetic modifications and gene expression deregulations.

17 Analyzes of chromosomal alterations in mesothelioma, performed by various techniques, such as

18 cytogenetic analysis of standard karyotype, classical CGH or SNP (single nucleotide

19 polymorphism) arrays, showed that numerous chromosomal abnormalities are associated with

20 MPM. They also resulted in a fairly reliable mapping of the recurrent altered regions (Jean et al.

21 2012; Melaiu et al. 2013). Recently, studies using high-resolution oligonucleotide microarrays

22 allowed to define smaller chromosome regions with biallelic deletion, which are potentially

23 informative about the presence of tumor suppressor genes (Klorin et al. 2013). Spectral

24 karyotyping (SKY) and RNA sequencing identified more precisely chromosome translocations in

25 MPM, whose recurrence remains to be determined (Klorin et al. 2013; Panagopoulos et al. 2013).

26 Methylome analyses by micro-array demonstrated that MPM are characterized by alterations of

27 the global epigenetic profile and show specific patterns of gene methylation as compared to 28 normal pleura or other tumors (Christensen et al. 2009; Goto et al. 2009). Specific DNA 29 methylation profile of MPM could be used as diagnostic and prognostic biomarker (Christensen

30 et al. 2009; Goto et al. 2009), but no precise epigenetic signature was defined since these two

31 initial publications (Vandermeers et al. 2013). However, recent data support the role of an 
1 epigenetic mechanism in mesothelial carcinogenesis by identifying new genes or miRNAs acting

2 as tumor suppressors, which are downregulated by DNA methylation (Cheng et al. 2013; Cioce et 3 al. 2014).

4 Transcriptome microarray studies on MPM are quite numerous, more than twenty before 2011.

5 They were carried out either on cultured cell lines either on tumor samples, and generally include

6 few tumor cases, three studies exceeding thirty cases (Gordon et al. 2003; Gordon et al. 2005;

7 Holloway et al. 2006) and one study approaching one hundred cases (Lopez-Rios et al. 2006).

8 These studies mainly focused on the comparison between MPM and normal pleura or mesothelial 9 cells, between histological subtypes of MPM or between MPM and other invasive or 10 metastasizing tumors in the pleura, mainly lung adenocarcinoma. The identified biomarkers were 11 listed in recent reviews (Jean et al. 2012; Melaiu et al. 2012). Given the inconsistency between 12 results of transcriptome studies, large independent series of MPM will be needed to validate 13 specific MPM biomarkers. Recently, expression deregulation of 59 of 119 biomarkers, selected 14 from data mining study combined with a literature review of transcriptomic studies, were 15 validated by RT-qPCR in an independent series of 22 MPM and 20 normal pleura (Melaiu et al. 16 2015). Transcriptomic approaches have a diagnostic interest as demonstrated by gene expression 17 ratio analysis (De Rienzo et al. 2013) and a prognostic interest as shown by older studies, which 18 defined predictors of survival based on gene expression (Gordon et al. 2009; Gordon et al. 2003; 19 Gordon et al. 2005; Lopez-Rios et al. 2006; Pass et al. 2004). These studies also allow to clarify 20 the molecular inter-tumor heterogeneity of MPM. Two older studies classified MPM into 21 subgroups, which correlated with histological types (Gordon et al. 2005; Hoang et al. 2004). 22 Recently, a classification of MPM in three molecular subtypes based on differences in gene 23 expression of 53 tumor samples was proposed with no correlation with clinical or histological 24 characteristics of the tumors (Suraokar et al. 2014). A classification in two molecular subtypes 25 was also defined from 38 cultured MPM primary cell lines and validated using 108 MPM tumor 26 samples. This classification is of interest as it is related partly to histological subtypes and allows 27 to separate epitheloid MPM in two subgroups of different survival outcome (de Reynies et al. 28 2014).

29 In the same way as for the transcriptomic studies, miRNome analyses focused mainly on the 30 differences between MPM and normal tissues or other types of cancer. These studies lead to the 31 identification of several potential MPM diagnosis biomarkers, which were summarized in a 
recent review (Reid 2015). The differences of miRNA expression between MPM histological subtypes were also considered. MiRNA expression levels may be also good biomarkers for predicting the prognosis as first mentioned in 2010 (Pass et al. 2010) and as investigated in several recent studies (Andersen et al. 2014; Kirschner et al. 2015; Matsumoto et al. 2014). These studies lead to the identification of individual miRNA, which expression is linked to prognosis such as miR-29c-5p, miR-193b or miR-31 or the establishment of predictive signature composed of several miRNAs. However, prognosis value validation of these miRNAs predictors is needed in larger independent MPM cohorts. Interestingly, the use of miRNAs as therapeutic targets is an emerging field in MPM even if the effectiveness of this strategy has been shown for the moment only in preclinical models (Reid et al. 2013; Ueno et al. 2014). There is a clinical trial in progress using miRNA-loaded nanocells, which derived from genetically-modified bacteria, for the delivery of miRNA in mesothelioma (Kao et al. 2015).

Integrated multi-omics studies on the same MPM cases should allow to better characterize the molecular features of MPM and to clarify the different pathways of mesothelial carcinogenesis. Unfortunately, integrated multi-omics studies are rare in MPM and incomplete. To our knowledge, only one study combined SNP and methylome arrays to analyze contributions of chromosomic and epigenetic alterations in MPM and revealed a strong association between global gene copy number alterations and global epigenetic dysregulation in MPM, rather than a discrete, local coordination of gene inactivation (Christensen et al. 2010), and two studies linked omic data to the mutation profile of the tumors. Lopez-Rios et al. analyzed genetic alterations of the $C D K N 2 A$ gene and performed a transcriptomic study using the same samples, but did not really integrate the result (Lopez-Rios et al. 2006). De Reynies et al. compared the distribution of the mutations in the main genes involved in mesothelial carcinogenesis (CDKN2A, NF2, BAP1 and TP53) in the two transcriptomic MPM subgroups they defined, showing a higher frequency of BAP1 mutation in the subgroup with the best prognosis (de Reynies et al. 2014). The analysis of TCGA (The Cancer Genome Atlas, https://tcga-data.nci.nih.gov) data, which include exome, SNP, methylation, mRNA and miRNA analysis on the same 87 MPM cases, would be a first step toward integrated approaches in MPM. Taking into account genetic and genomic data and also clinical, histological and epidemiological data will open important diagnostic and prognostic prospects and lead to the development of personalized medicine for patients. 


\section{Pathways deregulation}

3 During the past ten years, genetic and epigenetic studies have increased our understanding of the molecular pathogenesis of MPM. The results demonstrated that multiple signaling pathways are altered in mesothelioma. Alterations in cell cycle regulation were first detected by the deletion of

6 genes at the INK4 locus (Xio et al. 1995). The Hippo pathway was further identified due to the inactivation of NF2 gene (Sekido 2010). Alterations of other regulators of Hippo pathway, LATS1

8 and LATS2 and SAV1, and the overexpression of the transcription cofactor YAP have been

9 reported in some MPM (Jaurand and Jean 2016). Deregulation of this pathway can also occur via

10 the inhibition of merlin phosphatase, MYPT1-PP18, by protein kinase C-potentiated phosphatase

11 inhibitor (CPI-17), which is frequently overexpressed in MPM, leaving merlin in a

12 phosphorylated inactive form (Petrilli and Fernandez-Valle 2015; Thurneysen et al. 2009). Loss

13 of merlin could also lead to activate the E3 ubiquitin ligase, CRL4(DCAF1), which is inhibited

14 by its binding to the active, growth-inhibitory form of merlin in the nucleus (Petrilli and

15 Fernandez-Valle 2015).

16 Further studies have documented changes in the regulation of other pathways, from mutations in

17 key members and/or their differential expression in comparison to normal mesothelial cells. A 18 number of studies have emphasized the role of receptor tyrosine kinases (RTKs), which 19 activation leads to constitutive upregulation of two major downstream cell signaling cascades 20 involved in many regulations, including cell growth and survival i.e. Raf/MEK-extracellular 21 signal-regulated kinase and phosphoinositide-3 kinase (PI3K/AKT), and the mTOR downstream 22 signaling (Jaurand and Jean 2016; Jean et al. 2012; Sekido 2013). Our knowledge on the 23 deregulated pathways is increasing. Hedgehog pathway seems activated in MPM, possibly due to 24 mutations in members, receptors or regulators of the pathway such as PTCH1, SMO an SFU, and 25 its activation is associated with the worst clinical outcome (Felley-Bosco and Stahel 2014).

26 Several members of the WNT pathway have been reported as deregulated in MPM relative to 27 mesothelial cells, by the overexpression of agonists (WNTs, Dvl) or down regulation of 28 antagonists (SFRP4, WIF-1, Dvl) providing evidence for altered expression of a number of 29 Wnt/Fzd signaling molecules in MPM (de Assis, Locatelli, and Isoldi 2014; Fox et al. 2013; 30 Jaurand and Jean 2016; Pohl et al. 2015). 


\section{Stem cells}

2 Using side-population isolation or selection of tumor initiating cells, some studies have identified 3 populations of mesothelioma cells that express several putative cancer stem cell (CSC) markers 4 such as CD9, CD24, and CD26, ABCG2, OCT4/POU5F1 and nestin (Ghani et al. 2011; Pasdar et 5 al. 2015; Thies et al. 2015). These cells have interest as targets for pharmacological novel anti6 tumor drugs (Favoni et al. 2012). Further researches will likely be developed to better define the 7 characteristics of the cell types present in the tumor; more particularly their stemness 8 characteristics.

9 Recently, one study suggested that MPM originate as polyclonal tumors based on the methylation 10 status of the polymorphic human androgen receptor (HUMARA) locus (Comertpay et al. 2014).

11 Future studies including deep whole genome sequencing will precise the natural history of the 12 MPM and the clonal origin of MPM.

\section{Predisposing factors}

16 The role of factors that influence susceptibility to mineral fiber-induced diseases has been

17 recently reviewed, including age, gender and disease status, genetics, and nutrition as previously

18 reviewed (Below et al. 2011; Toumpanakis and Theocharis 2011). Several studies investigated on

19 polymorphism analyses of genes involved in xenobiotic and oxidative metabolism and DNA 20 repair systems such as, GSTT1, GSTM1, NAT2, CYP1A1, EPHX, XRCC1, XRCC3, RAD50,

$21 R A D 54 L$ and $R A D 21$, but no reproductive and clear-cut result was evidenced (Below et al. 2011;

22 Toumpanakis and Theocharis 2011). According to our knowledge no new findings have been

23 more recently published. However, the knowledge of single nucleotide polymorphism in genes of

24 the DNA repair system is of interest to account for the response to chemotherapy and 25 identification of biomarkers (Frischknecht et al. 2015; Panou et al. 2015; Peters et al. 2014).

26 The familial occurrence of mesothelioma has been observed since the 80's (Dawson et al. 1992).

27 More recently, $B A P 1$ was shown frequently mutated in several hereditary cancers, uveal 28 melanoma, cutaneous melanomas, basal cell carcinoma and renal cell carcinoma (Murali, 29 Wiesner, and Scolyer 2013). It has been suggested that BAPI mutations is implicated in an 30 hereditary cancer predisposition in a small subset of families with uveal melanoma and other 31 cancers, including mesothelioma (Abdel-Rahman et al. 2011). The discovery of BAPl germline 
1 mutations in two families with a high incidence of mesothelioma was first reported in 2011

2 (Testa et al. 2011). Further DNA sequencing in 26 sporadic MPM demonstrated 2 cases with 3 germline mutations in $B A P 1$, previously diagnosed for uveal melanoma. The $B A P 1$ mutational 4 status was studied in five multiplex families that showed malignant tumor predisposition, 5 including mesothelioma (Betti et al. 2015). Only one family carried a truncating germline 6 mutation suggesting that other genes may be involved in familial MPM predisposition syndrome 7 (Betti et al. 2015). In this study, all patients have been exposed to asbestos, most frequently by 8 household exposure, reported as low, due to occupational exposure of parents (Betti et al. 2015).

9 Recently, germinal DNA sequencing was carried out in sporadic MPM for BAP1 mutations. All 10 but one DNA showed a wild type sequence in 78 sporadic MPM, by Sanger sequencing (Rusch et 11 al. 2015), and all germline DNAs were wild-type in 22 mesothelioma samples (Nasu et al. 2015). 12 Sanger sequencing and MLPA analyses found no germinal mutation in 103 MPM samples. In an 13 analysis of PubMed databases identifying families studies with germline BAPl mutations in 14 mesothelioma (both pleural and peritoneal), and comparing to sporadic cases recorded in the 15 United States Surveillance, Epidemiology, and End Results (SEER) data from 1973 to 2010 , 16 patients with germline $B A P 1$ mutations in mesothelioma had a longer survival than without $B A P 1$ 17 mutation (Baumann, Flores, et al. 2015). Using tissue microarray analyses a prolonged survival 18 was also reported in mesothelioma with BAP1 loss (Arzt et al. 2014; Farzin et al. 2015)

19 These studies demonstrate that the risk of mesothelioma is influenced by BAPl germline 20 alterations, and mesothelioma can develop as a familial cancer syndrome (Sekido 2013). 21 Importantly, the presence of germline BAP1 mutations in sporadic MPM is very low; showing 22 that mesothelioma induction in asbestos-exposed patients is not a consequence of germline 23 mutation.

24 Immunohistochemistry (IHC) is an accessible method to determine protein expression, useful to 25 diagnosis and prognosis. The results reported in two publications suggest that IHC may be a 26 reliable method to identify BAPl mutations as they found a correlation between BAP1 expression 27 and mutations (Andrici et al. 2015; Nasu et al. 2015). Loss of BAP1 determined by IHC is 28 proposed as useful to support the diagnosis of mesothelioma. Loss of BAP1 and/or p16 ${ }^{\mathrm{INK} 4 \mathrm{~A}}$ by 29 IHC in well-identified mesothelial cells was recently considered as useful for cytological 30 diagnosis of mesothelioma, regarding the good correlation between the protein status in a series 
1 of 15 pairs biopsies/cytology samples (Hwang et al. 2015). However, further researches with a

2 greater number of cases are necessary to validate these results

4 CONCLUSIONS

6 The relationship between asbestos exposure and the development of MPM is well established,

7 and all epidemiological data have demonstrated that asbestos exposure is found in a large

8 percentage of MPM cases, with a higher risk for men than for women. The calculations of AR

9 show that the risk is much higher for men compared to women, for occupational exposure, while

10 it is the opposite for non-occupational exposures. However, when both types of exposures were

11 associated, the risk in women becomes closer that of men. Additional risk factors (other types of

12 fibers, irradiation) or cofactors (SV40) have emerged. MMVF now appear potential cofactors to

13 increase the risk of MPM. Epidemiological studies should be developed to investigate the risk of

14 multi-exposures associated with asbestos, including low doses, and to other new particles, 15 especially HARNs.

16 Many progresses have been made in our understanding of the biology of MPM and the molecular

17 changes occurring in MPM cells. From recent data, a role of $B A P 1$ in familial mesothelioma was

18 found, but germline mutations in BAPl are infrequent in sporadic mesothelioma. Except an

19 activating mutation in the promoter of TERT, somatic mutations have been found in tumor

20 suppressor genes. Overall, the number of genes with recurrent mutations is limited. In contrast,

21 there is a high rate of chromosome aberrations, mainly deletion of chromosome regions, leading

22 to gene copy number alterations; These genomic characteristics may be associated to the

23 mechanism of action of asbestos. Up to now, there is no signature of asbestos in MPM, but more

24 frequent losses in chromosomal 14q11 region were reported in exposed patients (Borczuk et al.

25 2016; Jean et al. 2011). NGS studies should allow to precise the genetic and genomic landscape

26 of MPM mutations. Characterization of the genetic changes in MPM from asbestos-exposed

27 patients would be of interest to better understand the mechanism of action of asbestos and would

28 be useful to study the effects of other EMPs.

29 The integration of "omics" studies should permit to develop a molecular pathophysiological

30 classification of MPM, which in addition to histological classification and clinical criteria should

31 improve diagnosis and therapeutic strategy. Unfortunately, MPM remains an incurable disease. 
1 Recent strategies focused on targeted therapies, but the molecular characteristics of the tumors

2 were not tested to determine the relevance of the drug on the basis of the molecular specificities

3 of the tumors and exposure. In the future, this knowledge should improve these new therapeutic

4 options, towards a therapy of precision for MPM.

5 Epidemiological studies have demonstrated that asbestos fibers are not the only carcinogenic 6 natural fibers and that the carcinogenic potency is not limited to amphibole fibers, either asbestos,

7 or non-asbestos. Our knowledge on exposure situations in workers demonstrated that the

8 hypothesis of a synergistic joint effect should be taken into consideration. Co-exposures to

9 asbestos and to some man-made fibers or to silica enhance the risk of mesothelioma. This should

10 be further investigated to better define the risk of mixed exposures that occur both in workers and

11 in the general population. Epidemiological data have also demonstrated that exposure to asbestos

12 and to other amphiboles or to erionite is not limited to occupational situations, but environmental

13 exposures have been linked to the occurrence of mesothelioma. Domestic exposures have been

14 early reported. In these situations, the level of exposure is lower than in workers' exposures. A 15 recent study found a consistent elevated risk of mesothelioma in the domestically exposed

16 populations. Simulations of low-level of chrysotile-exposed workers indicate asbestos levels

17 commensurate with background concentrations in those exposed domestically (Goswami et al. 18 2013).

19 On the basis of the mechanisms of carcinogenicity of asbestos, the biological effects of other 20 particles sharing some dimensional features with asbestos have been considered. Man-made 21 fibers and more recently EMPs are the subject of numerous studies. The current researches 22 benefited of the works on asbestos and led to consider the effects of CNTs. Although the weight 23 of evidence is insufficient, due to the variety of CNTs and limited number of studies for several 24 toxicity endpoints, it was found that some CNTs might pose danger for human health. The 25 development of researches on the molecular characteristics of MPM has a paramount interest for 26 a better classification of MPM, and definition of the different physio-pathological changes

27 specific of the tumors. This identification will permit to develop therapeutic strategies absolutely 28 needed for this orphan disease.

\section{Note}


1 During the review process of the manuscript, several relevant papers have been published. 2 Frequent SETDB1 mutations have been found in MPM (Kang et al. 2016). Otherwise, the genetic 3 landscape of MPM has been specified by reporting recurrent mutations, gene fusions and splicing 4 alterations in a large series of tumor samples (Bueno et al. 2016). A recent trial associating anti$5 \quad$ VEGF and anti-folate therapy has increased by three months the overall survival of patients with 6 MPM (Zalcman et al. 2015). Concerning the effects of CNTs, aberrant changes in mRNA and 7 ncRNA (non-coding RNA) expression profiles in the blood of workers, exposed or not exposed 8 to MWCNTs, have been reported (Shvedova et al. 2016). 


\section{REFERENCES}

Abdel-Rahman, M. H., R. Pilarski, C. M. Cebulla, J. B. Massengill, B. N. Christopher, G. Boru, P. Hovland, and F. H. Davidorf. 2011. Germline BAP1 mutation predisposes to uveal melanoma, lung adenocarcinoma, meningioma, and other cancers. J Med Genet 48:856859. DOI: 10.1136/jmedgenet-2011-100156.

Abdullayev, E., and Y. Lvov. 2011. Halloysite clay nanotubes for controlled release of protective agents. J Nanosci Nanotechnol 11:10007-10026.

Agudo, A., C. A. Gonzalez, M. J. Bleda, J. Ramirez, S. Hernandez, F. Lopez, A. Calleja, R. Panades, D. Turuguet, A. Escolar, M. Beltran, and J. E. Gonzalez-Moya. 2000. Occupation and risk of malignant pleural mesothelioma: A case-control study in Spain. Am J Ind Med 37:159-168.

Aguilar-Madrid, G., E. Robles-Perez, C. A. Juarez-Perez, I. Alvarado-Cabrero, F. G. RicoMendez, and K. G. Javier. 2010. Case-control study of pleural mesothelioma in workers with social security in Mexico. Am J Ind Med 53:241-251. DOI: 10.1002/ajim.20780.

Altomare, D. A., C. W. Menges, J. Xu, J. Pei, L. Zhang, A. Tadevosyan, E. Neumann-Domer, Z. Liu, M. Carbone, I. Chudoba, A. J. Klein-Szanto, and J. R. Testa. 2011. Losses of both products of the Cdkn2a/Arf locus contribute to asbestos-induced mesothelioma development and cooperate to accelerate tumorigenesis. PLoS One 6:e18828. DOI: 10.1371/journal.pone.0018828.

Andersen, M., M. Grauslund, J. Ravn, J. B. Sorensen, C. B. Andersen, and E. Santoni-Rugiu. 2014. Diagnostic potential of miR-126, miR-143, miR-145, and miR-652 in malignant pleural mesothelioma. J Mol Diagn 16:418-430. DOI: 10.1016/j.jmoldx.2014.03.002:.

Andrici, J., A. Sheen, L. Sioson, K. Wardell, A. Clarkson, N. Watson, M. S. Ahadi, M. Farzin, C. W. Toon, and A. J. Gill. 2015. Loss of expression of BAP1 is a useful adjunct, which strongly supports the diagnosis of mesothelioma in effusion cytology. Mod Pathol 28:1360-1368. DOI: 10.1038/modpathol.2015.87.

Antao, V. C., T. C. Larson, and D. K. Horton. 2012. Libby vermiculite exposure and risk of developing asbestos-related lung and pleural diseases. Curr Opin Pulm Med 18:161-167. DOI: 10.1097/MCP.0b013e32834e897d.

Arzt, L., F. Quehenberger, I. Halbwedl, T. Mairinger, and H. H. Popper. 2014. BAP1 protein is a progression factor in malignant pleural mesothelioma. Pathol Oncol Res 20:145-151. DOI: $10.1007 / \mathrm{s} 12253-013-9677-2$.

Aschberger, K., H. J. Johnston, V. Stone, R. J. Aitken, S. M. Hankin, S. A. Peters, C. L. Tran, and F. M. Christensen. 2010. Review of carbon nanotubes toxicity and exposure-appraisal of human health risk assessment based on open literature. Crit Rev Toxicol 40:759-790.

Bang, K. M., J. M. Mazurek, J. M. Wood, and S. A. Hendricks. 2014. Diseases attributable to asbestos exposure: years of potential life lost, United States, 1999-2010. Am J Ind Med 57:38-48. DOI: 10.1002/ajim.22261.

Baumann, F., B. J. Buck, R. V. Metcalf, B. T. McLaurin, D. J. Merkler, and M. Carbone. 2015. The Presence of Asbestos in the Natural Environment is Likely Related to Mesothelioma in Young Individuals and Women from Southern Nevada. J Thorac Oncol 10:731-737. DOI: $10.1097 /$ JTO.0000000000000506. 
Baumann, F., E. Flores, A. Napolitano, S. Kanodia, E. Taioli, H. Pass, H. Yang, and M. Carbone. 2015. Mesothelioma patients with germline BAP1 mutations have 7-fold improved longterm survival. Carcinogenesis 36:76-81. DOI: 10.1093/carcin/bgu227.

Baumann, F., P. Maurizot, M. Mangeas, J. P. Ambrosi, J. Douwes, and B. Robineau. 2011. Pleural mesothelioma in New Caledonia: associations with environmental risk factors. Environ Health Perspect 119:695-700. DOI: 10.1289/ehp.1002862.

Below, J. E., N. J. Cox, N. K. Fukagawa, A. Hirvonen, and J. R. Testa. 2011. Factors that impact susceptibility to fiber-induced health effects. J Toxicol Environ Health B Crit Rev 14:246266. DOI: $10.1080 / 10937404.2011 .556052$.

Betti, M., E. Casalone, D. Ferrante, A. Romanelli, F. Grosso, S. Guarrera, L. Righi, S. Vatrano, G. Pelosi, R. Libener, D. Mirabelli, R. Boldorini, C. Casadio, M. Papotti, G. Matullo, C. Magnani, and I. Dianzani. 2015. Inference on germline BAP1 mutations and asbestos exposure from the analysis of familial and sporadic mesothelioma in a high-risk area. Genes Chromosomes Cancer 54:51-62 DOI: 10.1002/gcc.22218.

Biggeri, A., R. Pasetto, S. Belli, C. Bruno, G. Di Maria, M. Mastrantonio, S. Trinca, R. Uccelli, and P. Comba. 2004. Mortality from chronic obstructive pulmonary disease and pleural mesothelioma in an area contaminated by natural fiber (fluoro-edenite). Scand $J$ Work Environ Health 30:249-252.

Boffetta, P., K. Donaldson, S. Moolgavkar, and J. S. Mandel. 2014. A systematic review of occupational exposure to synthetic vitreous fibers and mesothelioma. Crit Rev Toxicol 44:436-449. DOI: 10.3109/10408444.2014.899558.

Borczuk, A. C., J. Pei, R. N. Taub, B. Levy, O. Nahum, J. Chen, K. Chen, and J. R. Testa. 2016. Genome-wide analysis of abdominal and pleural malignant mesothelioma with DNA arrays reveals both common and distinct regions of copy number alteration. Cancer Biol Ther:1-8. DOI: 10.1080/15384047.2016.1145850.

Bott, M., M. Brevet, B. S. Taylor, S. Shimizu, T. Ito, L. Wang, J. Creaney, R. A. Lake, M. F. Zakowski, B. Reva, C. Sander, R. Delsite, S. Powell, Q. Zhou, R. Shen, A. Olshen, V. Rusch, and M. Ladanyi. 2011. The nuclear deubiquitinase BAP1 is commonly inactivated by somatic mutations and 3 p21.1 losses in malignant pleural mesothelioma. Nat Genet 43:668-672. DOI: 10.1038/ng.855.

Boulanger, G., P. Andujar, J. C. Pairon, M. A. Billon-Galland, C. Dion, P. Dumortier, P. Brochard, A. Sobaszek, P. Bartsch, C. Paris, and M. C. Jaurand. 2014. Quantification of short and long asbestos fibers to assess asbestos exposure: a review of fiber size toxicity. Environ Health 13:59. DOI: 10.1186/1476-069X-13-59:.

Bruno, C., R. Tumino, L. Fazzo, G. Cascone, A. Cernigliaro, M. De Santis, M. C. Giurdanella, C. Nicita, P. C. Rollo, S. Scondotto, E. Spata, A. Zona, and P. Comba. 2014. Incidence of pleural mesothelioma in a community exposed to fibres with fluoro-edenitic composition in Biancavilla (Sicily, Italy). Ann Ist Super Sanita 50:111-118. DOI: 10.4415/ANN_14_02_02.

Bueno, R., E. W. Stawiski, L. D. Goldstein, S. Durinck, A. De Rienzo, Z. Modrusan, F. Gnad, T. T. Nguyen, B. S. Jaiswal, L. R. Chirieac, D. Sciaranghella, N. Dao, C. E. Gustafson, K. J. Munir, J. A. Hackney, A. Chaudhuri, R. Gupta, J. Guillory, K. Toy, C. Ha, Y. J. Chen, J. Stinson, S. Chaudhuri, N. Zhang, T. D. Wu, D. J. Sugarbaker, F. J. de Sauvage, W. G. Richards, and S. Seshagiri. 2016. Comprehensive genomic analysis of malignant pleural mesothelioma identifies recurrent mutations, gene fusions and splicing alterations. Nat Genet. DOI: 10.1038/ng.3520. 
Bunderson-Schelvan, M., J. C. Pfau, R. Crouch, and A. Holian. 2011. Nonpulmonary outcomes of asbestos exposure. $J$ Toxicol Environ Health $B$ Crit Rev 14:122-152. 10.1080/10937404.2011.556048.

Camargo, M. C., L. T. Stayner, K. Straif, M. Reina, U. Al-Alem, P. A. Demers, and P. J. Landrigan. 2011. Occupational exposure to asbestos and ovarian cancer: a meta-analysis. Environ Health Perspect 119:1211-1217. DOI: 10.1289/ehp.1003283.

Camiade, E., C. Gramond, M. A. Jutand, S. Audignon, M. Rinaldo, E. Imbernon, D. Luce, F. Galateau-Salle, P. Astoul, J. C. Pairon, P. Brochard, and A. Lacourt. 2013. Characterization of a French series of female cases of mesothelioma. Am J Ind Med 56:1307-1316. DOI: 10.1002/ajim.22229.

Carbone, M., Y. I. Baris, P. Bertino, B. Brass, S. Cornertpay, A. Dogan, G. Gaudino, S. Jube, S. Kanodia, C.R. Partridge, H. Pass, Z. Rivera, I. Steele, M. Tuncer, S. Way, H. Yang, and A.. Miller. 2011. Erionite exposure in North Dakota and Turkish villages with mesothelioma Proc Natl Acad Sci U S A 108:13618-13623.

Carlin, D. J., T. C. Larson, J. C. Pfau, S. H. Gavett, A. Shukla, A. Miller, and R. Hines. 2015. Current Research and Opportunities to Address Environmental Asbestos Exposures. Environ Health Perspect 123:A194-197. DOI: 10.1289/ehp.1409662.

Case, B. W., J. L. Abraham, G. Meeker, F. D. Pooley, and K. E. Pinkerton. 2011. Applying definitions of "asbestos" to environmental and "low-dose" exposure levels and health effects, particularly malignant mesothelioma. J Toxicol Environ Health B Crit Rev 14:339. DOI: $10.1080 / 10937404.2011 .556045$.

Cheng, Y. Y., M. B. Kirschner, N. C. Cheng, S. Gattani, S. Klebe, J. J. Edelman, M. P. Vallely, B. C. McCaughan, H. C. Jin, N. van Zandwijk, and G. Reid. 2013. ZIC1 is silenced and has tumor suppressor function in malignant pleural mesothelioma. J Thorac Oncol 8:1317-1328. DOI: 10.1097/JTO.0b013e3182a0840a.

Chirieac, L. R., J. A. Barletta, B. Y. Yeap, W. G. Richards, T. Tilleman, R. Bueno, E. H. Baldini, J. Godleski, and D. J. Sugarbaker. 2013. Clinicopathologic characteristics of malignant mesotheliomas arising in patients with a history of radiation for Hodgkin and nonHodgkin lymphoma. J Clin Oncol 31:4544-4549. DOI: 10.1200/jco.2013.49.9616.

Christensen, B. C., E. A. Houseman, J. J. Godleski, C. J. Marsit, J. L. Longacker, C. R. Roelofs, M. R. Karagas, M. R. Wrensch, R. F. Yeh, H. H. Nelson, J. L. Wiemels, S. Zheng, J. K. Wiencke, R. Bueno, D. J. Sugarbaker, and K. T. Kelsey. 2009. Epigenetic profiles distinguish pleural mesothelioma from normal pleura and predict lung asbestos burden and clinical outcome. Cancer Res 69:227-234.

Christensen, B. C., E. A. Houseman, G. M. Poage, J. J. Godleski, R. Bueno, D. J. Sugarbaker, J. K. Wiencke, H. H. Nelson, C. J. Marsit, and K. T. Kelsey. 2010. Integrated Profiling Reveals a Global Correlation between Epigenetic and Genetic Alterations in Mesothelioma. Cancer Res 70:5686-5694.

Churg, A., T. Allen, A. C. Borczuk, P. T. Cagle, F. Galateau-Salle, H. Hwang, B. Murer, V. V. Murty, N. Ordonez, H. D. Tazelaar, and M. Wick. 2014. Well-differentiated papillary mesothelioma with invasive foci. Am J Surg Pathol 38:990-998. DOI: 10.1097/PAS.0000000000000200.

Cioce, M., F. Ganci, V. Canu, A. Sacconi, F. Mori, C. Canino, E. Korita, B. Casini, G. Alessandrini, A. Cambria, M. A. Carosi, R. Blandino, V. Panebianco, F. Facciolo, P. Visca, S. Volinia, P. Muti, S. Strano, C. M. Croce, H. I. Pass, and G. Blandino. 2014. Protumorigenic effects of mir-145 loss in malignant pleural mesothelioma. Oncogene 33:5319-5331. DOI: 10.1038/onc.2013.476. 
Clin, B., F. Morlais, G. Launoy, A. V. Guizard, B. Dubois, V. Bouvier, N. Desoubeaux, M. F. Marquignon, C. Raffaelli, C. Paris, F. Galateau-Salle, L. Guittet, and M. Letourneux. 2011. Cancer incidence within a cohort occupationally exposed to asbestos: a study of dose-response relationships. Occup Environ Med 68:832-836. DOI: 10.1136/oem.2010.059790.

Comba, P., A. Gianfagna, and L. Paoletti. 2003. Pleural mesothelioma cases in Biancavilla are related to a new fluoro-edenite fibrous amphibole. Arch Environ Health 58:229-232.

Comertpay, S., S. Pastorino, M. Tanji, R. Mezzapelle, O. Strianese, A. Napolitano, F. Baumann, T. Weigel, J. Friedberg, P. Sugarbaker, T. Krausz, E. Wang, A. Powers, G. Gaudino, S. Kanodia, H. I. Pass, B. L. Parsons, H. Yang, and M. Carbone. 2014. Evaluation of clonal origin of malignant mesothelioma. J Transl Med 12:301. DOI: 10.1186/s12967-014-03013.

Cooke, W. E. 1924. Fibrosis of the Lungs Due to the Inhalation of Asbestos Dust. $\mathrm{Br}$ Med $J$ 2:147-140 142 .

Cyphert, J. M., A. Nyska, R. K. Mahoney, M. C. Schladweiler, U. P. Kodavanti, and S. H. Gavett. 2012. Sumas Mountain chrysotile induces greater lung fibrosis in Fischer344 rats than Libby amphibole, El Dorado tremolite, and Ontario ferroactinolite. Toxicol Sci 130:405-415. DOI: $10.1093 /$ toxsci/kfs249.

Davidson, B. 2015. Prognostic factors in malignant pleural mesothelioma. Hum Pathol 46:789804. DOI: 10.1016/j.humpath.2015.02.006.

Dawson, A., A. Gibbs, K. Browne, F. Pooley, and M. Griffiths. 1992. Familial mesothelioma. Details of 17 cases with histopathologic findings and mineral analysis. Cancer 70:11831187.

de Assis, L. V., J. Locatelli, and M. C. Isoldi. 2014. The role of key genes and pathways involved in the tumorigenesis of Malignant Mesothelioma. Biochim Biophys Acta 1845:232-247. DOI: $10.1016 / \mathrm{j}$. bbcan.2014.01.008.

de Reynies, A, M. C. Jaurand, A. Renier, G. Couchy, I. Hysi, N. Elarouci, F. Galateau-Salle, M. C. Copin, P. Hofman, A. Cazes, P. Andujar, S. Imbeaud, F. Petel, J. C. Pairon, F. Le Pimpec-Barthes, J. Zucman-Rossi, and D. Jean. 2014. Molecular classification of malignant pleural mesothelioma: Identification of a poor prognosis subgroup linked to the epithelial-to-mesenchymal transition. Clin Cancer Res 20:1323-1334. DOI: 10.1158/1078-0432.CCR-13-242..

De Rienzo, A., W. G. Richards, B. Y. Yeap, M. H. Coleman, P. E. Sugarbaker, L. R. Chirieac, Y. E. Wang, J. Quackenbush, R. V. Jensen, and R. Bueno. 2013. Sequential binary gene ratio tests define a novel molecular diagnostic strategy for malignant pleural mesothelioma. Clin Cancer Res 19:2493-2502. DOI: 10.1158/1078-0432.CCR-12-2117.

Delgermaa, V., K. Takahashi, E. K. Park, G. V. Le, T. Hara, and T. Sorahan. 2011. Global mesothelioma deaths reported to the World Health Organization between 1994 and 2008. Bull World Health Organ 89:716-724. DOI: 10.2471/blt.11.086678.

Doll, R. 1955. Mortality from lung cancer in asbestos workers. Br J Ind Med 12:81-86.

Donaldson, K., and C. A. Poland. 2012. Inhaled nanoparticles and lung cancer - what we can learn from conventional particle toxicology. Swiss Med Wkly 142:w13547. DOI: 10.4414/smw.2012.13547.

Dunning, K. K., S. Adjei, L. Levin, A. M. Rohs, T. Hilbert, E. Borton, V. Kapil, C. Rice, G. K. Lemasters, and J. E. Lockey. 2012. Mesothelioma associated with commercial use of vermiculite containing Libby amphibole. J Occup Environ Med 54:1359-1363. DOI: 10.1097/JOM.0b013e318250b5f5. 
Fang, R., N. Le, and P. Band. 2011. Identification of occupational cancer risks in British Columbia, Canada: a population-based case-control study of 1,155 cases of colon cancer. Int J Environ Res Public Health 8:3821-3843. DOI: 10.3390/ijerph8103821.

Farioli, A., F. S. Violante, S. Mattioli, S. Curti, and D. Kriebel. 2013. Risk of mesothelioma following external beam radiotherapy for prostate cancer: a cohort analysis of SEER database. Cancer Causes Control 24:1535-1545. DOI: 10.1007/s10552-013-0230-0.

Farzin, M., C. W. Toon, A. Clarkson, L. Sioson, N. Watson, J. Andrici, and A. J. Gill. 2015. Loss of expression of BAP1 predicts longer survival in mesothelioma. Pathology 47:302-307. DOI: $10.1097 /$ pat.0000000000000250.

Fatkhutdinova, L. M., T. O. Khaliullin, and A. A. Shvedova. 2015. Carbon Nanotubes Exposure Risk Assessment: From Toxicology to Epidemiologic Studies (Overview of the Current Problem). Nanotechnol Russ 10:501-509.

Favoni, R. E., A. Daga, P. Malatesta, and T. Florio. 2012. Preclinical studies identify novel targeted pharmacological strategies for treatment of human malignant pleural mesothelioma. Br J Pharmacol 166:532-553. DOI: 10.1111/j.1476-5381.2012.01873.x.

Felley-Bosco, E., and R. Stahel. 2014. Hippo/YAP pathway for targeted therapy. Transl Lung Cancer Res 3:75-83. DOI: 10.3978/j.issn.2218-6751.2014.02.03.

Ferrante, D., D. Mirabelli, S. Tunesi, B. Terracini, and C. Magnani. 2015. Pleural mesothelioma and occupational and non-occupational asbestos exposure: a case-control study with quantitative risk assessment. Occup Environ Med In press. DOI: 10.1136/oemed-2015102803.

Fleury-Feith, J., C. Lecomte, A. Renier, M. Matrat, L. Kheuang, V. Abramowski, F. Levy, A. Janin, M. Giovannini, and M.C. Jaurand. 2003. Hemizygosity of $\mathrm{N} f 2$ is associated with increased susceptibility to asbestos-induced peritoneal tumours. Oncogene 22:3799-3805.

Forbes, S. A., D. Beare, P. Gunasekaran, K. Leung, N. Bindal, H. Boutselakis, M. Ding, S. Bamford, C. Cole, S. Ward, C. Y. Kok, M. Jia, T. De, J. W. Teague, M. R. Stratton, U. McDermott, and P. J. Campbell. 2015. COSMIC: exploring the world's knowledge of somatic mutations in human cancer. Nucleic Acids Res 43:D805-811. DOI: 10.1093/nar/gku1075.

Fortunato, L., and L. Rushton. 2015. Stomach cancer and occupational exposure to asbestos: a meta-analysis of occupational cohort studies. $\mathrm{Br} J$ Cancer 112:1805-1815. DOI: 10.1038/bjc.2014.599.

Fox, S. A., A. K. Richards, I. Kusumah, V. Perumal, E. M. Bolitho, S. E. Mutsaers, and A. M. Dharmarajan. 2013. Expression profile and function of Wnt signaling mechanisms in malignant mesothelioma cells. Biochem Biophys Res Commun 440:82-87. DOI: 10.1016/j.bbrc.2013.09.025.

Frank, A. L., and T. K. Joshi. 2014. The global spread of asbestos. Ann Glob Health 80:257-262. DOI: 10.1016/j.aogh.2014.09.016.

Frischknecht, L., M. Meerang, A. Soltermann, R. Stahel, H. Moch, B. Seifert, W. Weder, and I. Opitz. 2015. Importance of excision repair cross-complementation group 1 and ribonucleotide reductase M1 as prognostic biomarkers in malignant pleural mesothelioma treated with platinum-based induction chemotherapy followed by surgery. $J$ Thorac Cardiovasc Surg 149:1539-1546.e1531. DOI: 10.1016/j.jtcvs.2015.01.065.

Frost, G. 2013. The latency period of mesothelioma among a cohort of British asbestos workers (1978-2005). Br J Cancer 109:1965-1973. DOI: 10.1038/bjc.2013.514. 
Galateau-Salle, F., J. M. Vignaud, L. Burke, A. Gibbs, E. Brambilla, R. Attanoos, M. Goldberg, and G. Launoy. 2004. Well-differentiated papillary mesothelioma of the pleura: a series of 24 cases. Am J Surg Pathol 28:534-540.

Genaidy, A., T. Tolaymat, R. Sequeira, M. Rinder, and D. Dionysiou. 2009. Health effects of exposure to carbon nanofibers: systematic review, critical appraisal, meta analysis and research to practice perspectives. Sci Total Environ 407:3686-3701. DOI: 10.1016/j.scitotenv.2008.12.025.

Ghani, F. I., H. Yamazaki, S. Iwata, T. Okamoto, K. Aoe, K. Okabe, Y. Mimura, N. Fujimoto, T. Kishimoto, T. Yamada, C. W. Xu, and C. Morimoto. 2011. Identification of cancer stem cell markers in human malignant mesothelioma cells. Biochem Biophys Res Commun 404:735-742. DOI: 10.1016/j.bbrc.2010.12.054.

Gordon, G. J. , R. V. Jensen, L. L. Hsiao, S. R. Gullans, J. E. Blumenstock, W. G. Richards, M. T. Jaklitsch, D. J. Sugarbaker, and R. Bueno. 2003. Using gene expression ratios to predict outcome among patients with mesothelioma. J Natl Cancer Inst 95:598-605.

Gordon, G. J., L. Dong, B. Y. Yeap, W. G. Richards, J. N. Glickman, H. Edenfield, M. Mani, R. Colquitt, G. Maulik, B. Van Oss, D. J. Sugarbaker, and R. Bueno. 2009. Four-gene expression ratio test for survival in patients undergoing surgery for mesothelioma. $J$ Natl Cancer Inst 101:678-686.

Gordon, G. J., G. N. Rockwell, P. A. Godfrey, R. V. Jensen, J. N. Glickman, B. Y. Yeap, W. G. Richards, D. J. Sugarbaker, and R. Bueno. 2005. Validation of genomics-based prognostic tests in malignant pleural mesothelioma. Clin Cancer Res 11:4406-4414. DOI: 10.1158/1078-0432.CCR-04-2181.

Goswami, E., V. Craven, D. L. Dahlstrom, D. Alexander, and F. Mowat. 2013. Domestic asbestos exposure: a review of epidemiologic and exposure data. Int $J$ Environ Res Public Health 10:5629-5670. DOI: 10.3390/ijerph10115629.

Goto, Y., K. Shinjo, Y. Kondo, L. Shen, M. Toyota, H. Suzuki, W. Gao, B. An, M. Fujii, H. Murakami, H. Osada, T. Taniguchi, N. Usami, M. Kondo, Y. Hasegawa, K. Shimokata, K. Matsuo, T. Hida, N. Fujimoto, T. Kishimoto, J. P. Issa, and Y. Sekido. 2009. Epigenetic profiles distinguish malignant pleural mesothelioma from lung adenocarcinoma. Cancer Res 69:9073-9082.

Greim, H., M. J. Utell, L. D. Maxim, and R. Niebo. 2014. Perspectives on refractory ceramic fiber (RCF) carcinogenicity: comparisons with other fibers. Inhal Toxicol 26:789-810. DOI: $10.3109 / 08958378.2014 .953276$.

Grosse, Y., D. Loomis, K. Z. Guyton, B. Lauby-Secretan, F. El Ghissassi, V. Bouvard, L. Benbrahim-Tallaa, N. Guha, C. Scoccianti, H. Mattock, and K. Straif. 2014. Carcinogenicity of fluoro-edenite, silicon carbide fibres and whiskers, and carbon nanotubes. Lancet Oncol 15:1427-1428. DOI: 10.1016/s1470-2045(14)71109-x.

Guo, G., J. Chmielecki, C. Goparaju, A. Heguy, I. Dolgalev, M. Carbone, S. Seepo, M. Meyerson, and H. I. Pass. 2015. Whole exome sequencing reveals frequent genetic alterations in BAP1, NF2, CDKN2A and CUL1 in malignant pleural mesothelioma. Cancer Res 75:264-269. DOI: 10.1158/0008-5472.can-14-1008.

Hillegass, J. M., J. M. Miller, M. B. MacPherson, C. M. Westbom, M. Sayan, J. K. Thompson, S. L. Macura, T. N. Perkins, S. L. Beuschel, V. Alexeeva, H. I. Pass, C. Steele, B. T. Mossman, and A. Shukla. 2013. Asbestos and erionite prime and activate the NLRP3 inflammasome that stimulates autocrine cytokine release in human mesothelial cells. Part Fibre Toxicol 10:39. DOI: 10.1186/1743-8977-10-39. 
Hillerdal, G. 1999. Mesothelioma: cases associated with non-occupational and low dose exposures. Occup Environ Med 56:505-513.

Hoang, C. D., J. D'Cunha, M. G. Kratzke, C. E. Casmey, S. P. Frizelle, M. A. Maddaus, and R. A. Kratzke. 2004. Gene expression profiling identifies matriptase overexpression in malignant mesothelioma. Chest 125:1843-1852.

Holloway, A. J., D. S. Diyagama, K. Opeskin, J. Creaney, B. W. Robinson, R. A. Lake, and D. D. Bowtell. 2006. A molecular diagnostic test for distinguishing lung adenocarcinoma from malignant mesothelioma using cells collected from pleural effusions. Clin Cancer Res 12:5129-5135.

Husain, A. N., T. Colby, N. Ordonez, T. Krausz, R. Attanoos, M. B. Beasley, A. C. Borczuk, K. Butnor, P. T. Cagle, L. R. Chirieac, A. Churg, S. Dacic, A. Fraire, F. Galateau-Salle, A. Gibbs, A. Gown, S. Hammar, L. Litzky, A. M. Marchevsky, A. Nicholson, V. Roggli, W. D. Travis, and M. Wick. 2013. Guidelines for Pathologic Diagnosis of Malignant Mesothelioma: 2012 Update of the Consensus Statement from the International Mesothelioma Interest Group. Arch Pathol Lab Med 137:647-667. DOI: 10.5858/arpa.2012-0214-OA.

Hwang, H. C., B. S. Sheffield, S. Rodriguez, K. Thompson, C. H. Tse, A. M. Gown, and A. Churg. 2015. Utility of BAP1 Immunohistochemistry and p16 (CDKN2A) FISH in the Diagnosis of Malignant Mesothelioma in Effusion Cytology Specimens. Am J Surg Pathol 40:120-126. DOI: 10.1097/pas.0000000000000529.

IARC. 2002. Man-made vitreous fibres. Vol. 81, IARC Monograph on the valuation of carcinogenic risks to humans. Lyon: IARC Press.

IARC. 2012. Arsenic, metals, fibres, and dusts. A review of human carcinogens Vol. $100 \mathrm{C}$ IARC Monographs on the Evaluation of Carcinogenic Risks to Humans. Lyon: IARC Press.

Jasani, B., and A. Gibbs. 2012. Mesothelioma not associated with asbestos exposure. Arch Pathol Lab Med 136:262-267. DOI: 10.5858/arpa.2011-0039-RA.

Jaurand, M. C. 2015. Health effects of carbon nanotubes and some comparisons with natural mineral nanotubes. In Natural mineral nanotubes. Properties and applications, edited by P. Pooria Pasbakhsh, and G. Jock Churchman, PhD. Oakville, ON L6L 0A2, Canada: Apple Academic Press.

Jaurand, M. C. In press. Safety of tubular clay minerals: an overview. In Nanosized Tubular Clay Minerals edited by P. Yuan, A. Thill and F. Bergaya: Elsevier.

Jaurand, M. C., and D. Jean. 2016. Biomolecular Pathways and Malignant Pleural Mesothelioma. In Malignant Pleural Mesothelioma: Present Status and Future Directions, edited by T. C. Mineo. Sharjah, U.A.E.: Bentham Science Publishers.

Jean, D., J. Daubriac, F. Le Pimpec-Barthes, F. Galateau-Salle, and M. C. Jaurand. 2012. Molecular changes in mesothelioma with an impact on prognosis and treatment. Arch Pathol Lab Med 136:277-293. DOI: 10.5858/arpa.2011-0215-RA.

Jean, D., E. Thomas, A. Renier, A. de Reynies, C. Lecomte, P. Andujar, J. Fleury-Feith, M. Giovannini, J. Zucman-Rossi, M.H. Stern, and M. C. Jaurand. 2011. Syntenic relationships between genomic profiles of fiber-induced murine and human malignant mesothelioma. Am J Pathol 176:881-894.

Kameda, T., K. Takahashi, R. Kim, Y. Jiang, M. Movahed, E. K. Park, and J. Rantanen. 2014. Asbestos: use, bans and disease burden in Europe. Bull World Health Organ 92:790-797. DOI: $10.2471 /$ BLT.13.132118.

Kanarek, M. S. 2011. Mesothelioma from chrysotile asbestos: update. Ann Epidemiol 21:688697. DOI: 10.1016/j.annepidem.2011.05.010. 
Kang, H. C., H. K. Kim, S. Lee, P. Mendez, J. W. Kim, G. Woodard, J. H. Yoon, K. Y. Jen, L. T. Fang, K. Jones, D. M. Jablons, and I. J. Kim. 2016. Whole exome and targeted deep sequencing identify genome-wide allelic loss and frequent SETDB1 mutations in malignant pleural mesotheliomas. Oncotarget. DOI: 10.18632/oncotarget.7032.

Kao, S. C., M. Fulham, K. Wong, W. Cooper, H. Brahmbhatt, J. MacDiarmid, S. Pattison, J. O. Sagong, Y. Huynh, F. Leslie, N. Pavlakis, S. Clarke, M. Boyer, G. Reid, and N. van Zandwijk. 2015. A Significant Metabolic and Radiological Response after a Novel Targeted MicroRNA-based Treatment Approach in Malignant Pleural Mesothelioma. Am J Respir Crit Care Med 191:1467-1469. DOI: 10.1164/rccm.201503-0461LE.

Kayat, J., V. Gajbhiye, R. K. Tekade, and N. K. Jain. 2011. Pulmonary toxicity of carbon nanotubes: a systematic report. Nanomedicine 7:40-49. DOI: 10.1016/j.nano.2010.06.008.

Kirschner, M. B., Y. Y. Cheng, N. J. Armstrong, R. C. Lin, S. C. Kao, A. Linton, S. Klebe, B. C. McCaughan, N. van Zandwijk, and G. Reid. 2015. MiR-score: a novel 6-microRNA signature that predicts survival outcomes in patients with malignant pleural mesothelioma. Mol Oncol 9:715-726. DOI: 10.1016/j.molonc.2014.11.007.

Klorin, G., E. Rozenblum, O. Glebov, R. L. Walker, Y. Park, P. S. Meltzer, I. R. Kirsch, F. J. Kaye, and A. V. Roschke. 2013. Integrated high-resolution array CGH and SKY analysis of homozygous deletions and other genomic alterations present in malignant mesothelioma cell lines. Cancer Genet 206:191-205. DOI: 10.1016/j.cancergen.2013.04.006.

Kodavanti, U. P., D. Andrews, M. C. Schladweiler, S. H. Gavett, D. E. Dodd, and J. M. Cyphert. 2014. Early and delayed effects of naturally occurring asbestos on serum biomarkers of inflammation and metabolism. $J$ Toxicol Environ Health A 77:1024-1039. DOI: 10.1080/15287394.2014.899171.

Kurumatani, N., and S. Kumagai. 2008. Mapping the risk of mesothelioma due to neighborhood asbestos exposure. Am J Respir Crit Care Med 178:624-629. DOI: 10.1164/rccm.200801063OC.

Lacourt, A., C. Gramond, S. Audignon, S. Ducamp, J. Fevotte, A. G. Soit Ilg, M. Goldberg, E. Imbernon, and P. Brochard. 2013. Pleural mesothelioma and occupational coexposure to asbestos, mineral wool, and silica. Am J Respir Crit Care Med 187:977-982. DOI: 10.1164/rccm.201210-19110C.

Lacourt, A., M. Rinaldo, C. Gramond, S. Ducamp, A. Gilg Soit Ilg, M. Goldberg, J. C. Pairon, and P. Brochard. 2014. Co-exposure to refractory ceramic fibres and asbestos and risk of pleural mesothelioma. Eur Respir J 44:725-733. DOI: 10.1183/09031936.00079814.

Langevin, S. M., M. H. O'Sullivan, J. L. Valerio, M. Pawlita, K. M. Applebaum, M. Eliot, M. D. McClean, and K. T. Kelsey. 2013. Occupational asbestos exposure is associated with pharyngeal squamous cell carcinoma in men from the greater Boston area. Occup Environ Med 70:858-863. DOI: 10.1136/oemed-2013-101528.

Lecouvet, B. 2015. Some further industrial, environmental and biomedical applications of halloysite nanotubes. In Natural mineral nanotubes. Properties and applications, edited by P. P. Pasbakhsh and P. G.J. Churchman. Oakville, ON L6L 0A2, Canada: Apple Academic Press.

Li, B., S. P. Tang, and K. Z. Wang. 2015. Esophagus cancer and occupational exposure to asbestos: results from a meta-analysis of epidemiology studies. Dis Esophagus In press. DOI: $10.1111 /$ dote.12341.

Lim, C. B., C. M. Prele, H. M. Cheah, Y. Y. Cheng, S. Klebe, G. Reid, D. N. Watkins, S. Baltic, P. J. Thompson, and S. E. Mutsaers. 2013. Mutational analysis of hedgehog signaling 
pathway genes in human malignant mesothelioma. PLoS ONE 8:e66685. DOI: 10.1371/journal.pone.0066685.

Lippmann, M. 2014. Toxicological and epidemiological studies on effects of airborne fibers: coherence and public [corrected] health implications. Crit Rev Toxicol 44:643-695. DOI: 10.3109/10408444.2014.928266.

Lo Iacono, M., V. Monica, L. Righi, F. Grosso, R. Libener, S. Vatrano, P. Bironzo, S. Novello, L. Musmeci, M. Volante, M. Papotti, and G. V. Scagliotti. 2015. Targeted next-generation sequencing of cancer genes in advanced stage malignant pleural mesothelioma: a retrospective study. J Thorac Oncol 10:492-499. DOI: 10.1097/jto.0000000000000436.

Lockey, J. E., G. K. LeMasters, L. Levin, C. Rice, J. Yiin, S. Reutman, and D. Papes. 2002. A longitudinal study of chest radiographic changes of workers in the refractory ceramic fiber industry. Chest 121:2044-2051.

Lockey, J., G. Lemsters, C. Rice, K. Hansen, L. Levin, R. Shipley, H. Spitz, and J. Wiot. 1996. Refractory ceramic fiber exposure and pleural plaques. Am J Respir Crit Care Med 154:1405-1410.

Lopez-Rios, F., S. Chuai, R. Flores, S. Shimizu, T. Ohno, K. Wakahara, P. B. Illei, S. Hussain, L. Krug, M. F. Zakowski, V. Rusch, A. B. Olshen, and M. Ladanyi. 2006. Global gene expression profiling of pleural mesotheliomas: overexpression of aurora kinases and P16/CDKN2A deletion as prognostic factors and critical evaluation of microarray-based prognostic prediction. Cancer Res 66:2970-2979.

Maisanaba, S., S. Pichardo, M. Puerto, D. Gutierrez-Praena, A. M. Camean, and A. Jos. 2015. Toxicological evaluation of clay minerals and derived nanocomposites: a review. Environ Res 138:233-254. DOI: 10.1016/j.envres.2014.12.024.

Matsumoto, S., K. Nabeshima, M. Hamasaki, T. Shibuta, and T. Umemura. 2014. Upregulation of microRNA-31 associates with a poor prognosis of malignant pleural mesothelioma with sarcomatoid component. Med Oncol 31:303. DOI: 10.1007/s12032-014-0303-2.

Melaiu, O., E. Bracci, A. Cristaudo, A. Bonotti, R. Foddis, L. Mutti, F. Gemignani, and S. Landi. 2013. Comparative Genomic Hybridization Studies on Mesothelioma Show a Parallel Fate of 1p21-1p22 and 9p21 Bands and a Chromosomally Stable Sub-Group. American Journal of Medical and Biological Research. 1:149-158.

Melaiu, O., A. Cristaudo, E. Melissari, M. Di Russo, A. Bonotti, R. Bruno, R. Foddis, F. Gemignani, S. Pellegrini, and S. Landi. 2012. A review of transcriptome studies combined with data mining reveals novel potential markers of malignant pleural mesothelioma. Mutat Res 750:132-140.

Melaiu, O., E. Melissari, L. Mutti, E. Bracci, C. De Santi, C. Iofrida, M. Di Russo, A. Cristaudo, A. Bonotti, M. Cipollini, S. I. Garritano, R. Foddis, M. Lucchi, S. Pellegrini, F. Gemignani, and S. Landi. 2015. Expression status of candidate genes in mesothelioma tissues and cell lines. Mutat Res 771:6-12. DOI: 10.1016/j.mrfmmm.2014.11.002.

Menvielle, G., A. Fayosse, L. Radoi, F. Guida, M. Sanchez, M. Carton, D. Cyr, A. Schmaus, S. Cenee, J. Fevotte, P. Delafosse, I. Stucker, and D. Luce. 2016. The joint effect of asbestos exposure, tobacco smoking and alcohol drinking on laryngeal cancer risk: evidence from the French population-based case-control study, ICARE. Occup Environ Med 73:28-33. DOI: 10.1136/oemed-2015-102954.

Mezzapelle, R., U. Miglio, O. Rena, A. Paganotti, S. Allegrini, J. Antona, F. Molinari, M. Frattini, G. Monga, O. Alabiso, and R. Boldorini. 2013. Mutation analysis of the EGFR gene and downstream signalling pathway in histologic samples of malignant pleural mesothelioma. Br J Cancer 108:1743-1749. DOI: 10.1038/bjc.2013.130. 
Miyanaga, A., M. Masuda, K. Tsuta, K. Kawasaki, Y. Nakamura, T. Sakuma, H. Asamura, A. Gemma, and T. Yamada. 2015. Hippo pathway gene mutations in malignant mesothelioma: revealed by RNA and targeted exon sequencing. J Thorac Oncol 10:844851. DOI: $10.1097 /$ jto.0000000000000493.

Murakami, H., T. Mizuno, T. Taniguchi, M. Fujii, F. Ishiguro, T. Fukui, S. Akatsuka, Y. Horio, T. Hida, Y. Kondo, S. Toyokuni, H. Osada, and Y. Sekido. 2011. LATS2 Is a Tumor Suppressor Gene of Malignant Mesothelioma. Cancer Res 71:873-883. DOI: 10.1158/0008-5472.CAN-10-2164.

Murali, R., T. Wiesner, and R. A. Scolyer. 2013. Tumours associated with BAP1 mutations. Pathology 45:116-126. DOI: 10.1097/PAT.0b013e32835d0efb.

Musk, A. W., N. Olsen, H. Alfonso, A. Reid, R. Mina, P. Franklin, J. Sleith, N. Hammond, T. Threlfall, K. B. Shilkin, and N. H. de Klerk. 2011. Predicting survival in malignant mesothelioma. Eur Respir J 38:1420-1424. DOI: 10.1183/09031936.00000811.

Nasu, M., M. Emi, S. Pastorino, M. Tanji, A. Powers, H. Luk, F. Baumann, Y. A. Zhang, A. Gazdar, S. Kanodia, M. Tiirikainen, E. Flores, G. Gaudino, M. J. Becich, H. I. Pass, H. Yang, and M. Carbone. 2015. High Incidence of Somatic BAP1 alterations in sporadic malignant mesothelioma. $J$ Thorac Oncol 10:565-576. DOI: 10.1097/jto.0000000000000471.

NIOSH. 2011. Asbestos fibers and other elongate mineral particles: State of the science and roadmap for research. Revised April 2011. Current Intelligence Bulletin 62 1-153.

Offermans, N. S., R. Vermeulen, A. Burdorf, R. A. Goldbohm, T. Kauppinen, H. Kromhout, and P. A. van den Brandt. 2014. Occupational asbestos exposure and risk of pleural mesothelioma, lung cancer, and laryngeal cancer in the prospective Netherlands cohort study. J Occup Environ Med 56:6-19. DOI: 10.1097/JOM.0000000000000060.

Offermans, N. S., R. Vermeulen, A. Burdorf, R. A. Goldbohm, A. P. Keszei, S. Peters, T. Kauppinen, H. Kromhout, and P. A. van den Brandt. 2014. Occupational asbestos exposure and risk of esophageal, gastric and colorectal cancer in the prospective Netherlands Cohort Study. Int J Cancer 135:1970-1977. DOI: 10.1002/ijc.28817.

Ortega-Guerrero, M. A., G. Carrasco-Nunez, H. Barragan-Campos, and M. R. Ortega. 2015. High incidence of lung cancer and malignant mesothelioma linked to erionite fibre exposure in a rural community in Central Mexico. Occup Environ Med 72:216-218. DOI: 10.1136/oemed-2013-101957.

Pairon, J. C., P. Andujar, M. Rinaldo, J. Ameille, P. Brochard, S. Chamming's, B. Clin, G. Ferretti, A. Gislard, F. Laurent, A. Luc, P. Wild, and C. Paris. 2014. Asbestos exposure, pleural plaques, and the risk of death from lung cancer. Am J Respir Crit Care Med 190:1413-1420. DOI: 10.1164/rccm.201406-1074OC.

Pairon, J. C., F. Laurent, M. Rinaldo, B. Clin, P. Andujar, J. Ameille, P. Brochard, S. Chammings, G. Ferretti, F. Galateau-Salle, A. Gislard, M. Letourneux, A. Luc, E. Schorle, and C. Paris. 2013. Pleural plaques and the risk of pleural mesothelioma. J Natl Cancer Inst 105:293-301.

Panagopoulos, I., J. Thorsen, L. Gorunova, F. Micci, L. Haugom, B. Davidson, and S. Heim. 2013. RNA sequencing identifies fusion of the EWSR1 and YY1 genes in mesothelioma with $\mathrm{t}(14 ; 22)(\mathrm{q} 32 ; \mathrm{q} 12)$. Genes Chromosomes Cancer 52:733-740. DOI: $10.1002 /$ gcc. 22068 .

Panou, V., M. Vyberg, U. M. Weinreich, C. Meristoudis, U. G. Falkmer, and O. D. Roe. 2015. The established and future biomarkers of malignant pleural mesothelioma. Cancer Treat Rev 41:486-495. DOI: 10.1016/j.ctrv.2015.05.001. 
Pasdar, E. A., M. Smits, M. Stapelberg, M. Bajzikova, M. Stantic, J. Goodwin, B. Yan, J. Stursa, J. Kovarova, K. Sachaphibulkij, A. Bezawork-Geleta, M. Sobol, A. Filimonenko, M. Tomasetti, R. Zobalova, P. Hozak, L. F. Dong, and J. Neuzil. 2015. Characterisation of mesothelioma-initiating cells and their susceptibility to anti-cancer agents. PLOS ONE 10:e119549. DOI: 10.1371/journal.pone.0119549.

Pass, H. I., C. Goparaju, S. Ivanov, J. Donington, M. Carbone, M. Hoshen, D. Cohen, A. Chajut, S. Rosenwald, H. Dan, S. Benjamin, and R. Aharonov. 2010. hsa-miR-29c* Is Linked to the Prognosis of Malignant Pleural Mesothelioma. Cancer Res 70:1916-1924.

Pass, H. I., Z. Liu, A. Wali, R. Bueno, S. Land, D. Lott, F. Siddiq, F. Lonardo, M. Carbone, and S. Draghici. 2004. Gene expression profiles predict survival and progression of pleural mesothelioma. Clin Cancer Res 10:849-859.

Peters, G. J., A. Avan, M. G. Ruiz, V. Orsini, A. Avan, E. Giovannetti, and E. F. Smit. 2014. Predictive role of repair enzymes in the efficacy of Cisplatin combinations in pancreatic and lung cancer. Anticancer Res 34:435-442.

Petrilli, A. M., and C. Fernandez-Valle. 2015. Role of Merlin/NF2 inactivation in tumor biology. Oncogene 35:537-548. DOI: 10.1038/onc.2015.125.

Pintos, J., M. E. Parent, B. W. Case, M. C. Rousseau, and J. Siemiatycki. 2009. Risk of mesothelioma and occupational exposure to asbestos and man-made vitreous fibers: evidence from two case-control studies in Montreal, Canada. J Occup Environ Med 51:1177-1184.

Pohl, S., R. Scott, F. Arfuso, V. Perumal, and A. Dharmarajan. 2015. Secreted frizzled-related protein 4 and its implications in cancer and apoptosis. Tumour Biol 36:143-152. DOI: 10.1007/s13277-014-2956-z.

Pukkala, E., J. I. Martinsen, E. Weiderpass, K. Kjaerheim, E. Lynge, L. Tryggvadottir, P. Sparen, and P. A. Demers. 2014. Cancer incidence among firefighters: 45 years of follow-up in five Nordic countries. Occup Environ Med 71:398-404. DOI: 10.1136/oemed-2013101803.

Rake, C., C. Gilham, J. Hatch, A. Darnton, J. Hodgson, and J. Peto. 2009. Occupational, domestic and environmental mesothelioma risks in the British population: a case-control study. Br J Cancer 100:1175-1183. DOI: 10.1038/sj.bjc.6604879.

Rapisarda, V., C. Ledda, V. Ricceri, F. Arena, A. Musumeci, A. Marconi, L. Fago, M. Bracci, L. Santarelli, and M. Ferrante. 2015. Detection of pleural plaques in workers exposed to inhalation of natural fluoro-edenite fibres. Oncol Lett 9:2046-2052. DOI: 10.3892/ol.2015.2978.

Reid, A., P. Franklin, N. Olsen, J. Sleith, L. Samuel, P. Aboagye-Sarfo, N. de Klerk, and A. W. Musk. 2013. All-cause mortality and cancer incidence among adults exposed to blue asbestos during childhood. Am J Ind Med 56:133-145. DOI: 10.1002/ajim.22103.

Reid, G. 2015. MicroRNAs in mesothelioma: from tumour suppressors and biomarkers to therapeutic targets. $J$ Thorac Dis 7:1031-1040. DOI: 10.3978/j.issn.20721439.2015.04.56.

Robinson, B. W., A. W. Musk, and R. A. Lake. 2005. Malignant mesothelioma. Lancet 366:397408. DOI: $10.1016 / \mathrm{S} 0140-6736(05) 67025-0$.

Rodelsperger, K., K. H. Jockel, H. Pohlabeln, W. Romer, and H. J. Woitowitz. 2001. Asbestos and man-made vitreous fibers as risk factors for diffuse malignant mesothelioma: results from a German hospital-based case-control study. Am J Ind Med 39:262-275.

Rolland, P., C. Gramond, A. Lacourt, P. Astoul, S. Chamming's, S. Ducamp, C. Frenay, F. Galateau-Salle, A. G. Ilg, E. Imbernon, N. Le Stang, J. C. Pairon, M. Goldberg, and P. 
Brochard. 2010. Occupations and industries in France at high risk for pleural mesothelioma: A population-based case-control study (1998-2002). Am J Ind Med 53:1207-1219. DOI: 10.1002/ajim.20895.

Rusch, A., G. Ziltener, K. Nackaerts, W. Weder, R. A. Stahel, and E. Felley-Bosco. 2015. Prevalence of BRCA-1 associated protein 1 germline mutation in sporadic malignant pleural mesothelioma cases. Lung Cancer 87:77-79. DOI: 10.1016/j.lungcan.2014.10.017. Scherpereel, A., P. Astoul, P. Baas, T. Berghmans, H. Clayson, P. de Vuyst, H. Dienemann, F. Galateau-Salle, C. Hennequin, G. Hillerdal, C. Le Pechoux, L. Mutti, J. C. Pairon, R. Stahel, P. van Houtte, J. van Meerbeeck, D. Waller, and W. Weder. 2010. Guidelines of the European Respiratory Society and the European Society of Thoracic Surgeons for the management of malignant pleural mesothelioma. Eur Respir J 35:479-495.

Schildgen, V., O. Pabst, R. L. Tillmann, J. Lusebrink, O. Schildgen, C. Ludwig, M. Brockmann, and E. Stoelben. 2015. Low frequency of EGFR mutations in pleural mesothelioma patients, Cologne, Germany. Appl Immunohistochem Mol Morphol 23:118-125. DOI: 10.1097/PDM.0b013e3182a3645e.

Sebastien, P., A. Fondimare, J. Bignon, G. Monchaux, J. Desbordes, and G. Bonnaud. 1975. Topographic distribution of asbestos fibres in human lung in relation to occupational and non-occupational exposure. Inhaled Part 4 Pt 2:435-446.

Sekido, Y. 2010. Genomic abnormalities and signal transduction dysregulation in malignant mesothelioma cells. Cancer Sci 101:1-6.

Sekido, Y. 2013. Molecular pathogenesis of malignant mesothelioma. Carcinogenesis 34:14131419. DOI: $10.1093 /$ carcin/bgt166.

Selikoff, I. J., J. Churg, and E. C. Hammond. 1964. Asbestos exposure and neoplasia. Jama 188:22-26.

Shukuya, T., M. Serizawa, M. Watanabe, H. Akamatsu, M. Abe, H. Imai, T. Tokito, A. Ono, T. Taira, H. Kenmotsu, T. Naito, H. Murakami, T. Takahashi, M. Endo, Y. Ohde, T. Nakajima, N. Yamamoto, and Y. Koh. 2014. Identification of actionable mutations in malignant pleural mesothelioma. Lung Cancer 86:35-40. DOI: 10.1016/j.lungcan.2014.08.004.

Shvedova, A. A., E. R. Kisin, D. Porter, P. Schulte, V. E. Kagan, B. Fadeel, and V. Castranova. 2009. Mechanisms of pulmonary toxicity and medical applications of carbon nanotubes: Two faces of Janus? Pharmacol Ther 121:192-204.

Shvedova, A. A., N. Yanamala, E. R. Kisin, T. O. Khailullin, M. E. Birch, and L. M. Fatkhutdinova. 2016. Integrated Analysis of Dysregulated ncRNA and mRNA Expression Profiles in Humans Exposed to Carbon Nanotubes. PLoS One 11:e0150628. DOI: 10.1371/journal.pone.0150628.

Simson, F.W. 1928. Pulmonary asbestosis in South Africa. Br Med J 1 (3516):885-887. DOI: doi: http://dx.doi.org/10.1136/bmj.1.3516.885 (Published 26 May 1928).

Spirtas, R., E. F. Heineman, L. Bernstein, G. W. Beebe, R. J. Keehn, A. Stark, B. L. Harlow, and J. Benichou. 1994. Malignant mesothelioma: attributable risk of asbestos exposure. Occup Environ Med 51:804-811.

Stayner, L., L. S. Welch, and R. Lemen. 2013. The worldwide pandemic of asbestos-related diseases. Annu Rev Public Health 34:205-216. DOI: 10.1146/annurev-publhealth-031811124704.

Suraokar, M. B., M. I. Nunez, L. Diao, C. W. Chow, D. Kim, C. Behrens, H. Lin, S. Lee, G. Raso, C. Moran, D. Rice, R. Mehran, J. J. Lee, H. I. Pass, J. Wang, A. A. Momin, B. P. James, A. Corvalan, K. Coombes, A. Tsao, and Wistuba, II. 2014. Expression profiling 
stratifies mesothelioma tumors and signifies deregulation of spindle checkpoint pathway and microtubule network with therapeutic implications. Ann Oncol 25:1184-1192. DOI: 10.1093/annonc/mdu127.

Tallet, A., J. C. Nault, A. Renier, I. Hysi, F. Galateau-Salle, A. Cazes, M. C. Copin, P. Hofman, P. Andujar, F. Le Pimpec-Barthes, J. Zucman-Rossi, M. C. Jaurand, and D. Jean. 2014. Overexpression and promoter mutation of the TERT gene in malignant pleural mesothelioma. Oncogene 33:3748-3452.

Tarres, J., C. Alberti, X. Martinez-Artes, R. Abos-Herrandiz, M. Rosell-Murphy, I. Garcia-Allas, I. Krier, G. Cantarell, M. Gallego, J. Canela-Soler, and R. Orriols. 2013. Pleural mesothelioma in relation to meteorological conditions and residential distance from an industrial source of asbestos. Occup Environ Med 70:588-590. DOI: 10.1136/oemed2012-101198.

Testa, J. R., M. Cheung, J. Pei, J. E. Below, Y. Tan, E. Sementino, N. J. Cox, A. U. Dogan, H. I. Pass, S. Trusa, M. Hesdorffer, M. Nasu, A. Powers, Z. Rivera, S. Comertpay, M. Tanji, G. Gaudino, H. Yang, and M. Carbone. 2011. Germline BAP1 mutations predispose to malignant mesothelioma. Nat Genet 43:1022-1025. DOI: 10.1038/ng.912.

Thies, S., M. Friess, L. Frischknecht, D. Korol, E. Felley-Bosco, R. Stahel, B. Vrugt, W. Weder, I. Opitz, and A. Soltermann. 2015. Expression of the Stem Cell Factor Nestin in Malignant Pleural Mesothelioma Is Associated with Poor Prognosis. PLoS ONE 10:e0139312. DOI: 10.1371/journal.pone.0139312.

Thurneysen, C., I. Opitz, S. Kurtz, W. Weder, R. A. Stahel, and E. Felley-Bosco. 2009. Functional inactivation of NF2/merlin in human mesothelioma. Lung Cancer 64:140-147. DOI: 10.1016/j.lungcan.2008.08.014.

Toumpanakis, D., and S. E. Theocharis. 2011. DNA repair systems in malignant mesothelioma. Cancer Lett 312:143-149. DOI: 10.1016/j.canlet.2011.08.021.

Tran, C. L., R. Trantra, K. Donaldson, V. Stone, S.M. Hankin, B. Ross, R.J. Aitknen, and A. D. Jones. 2011. A hypothetical model for predicting the toxicity of high aspect ratio nanoparticles (HARN). J Nanopart Res 13:6683-6698. DOI 10.1007/s11051-011-0575-9.

Tran, P. A., L. Zhang, and T. J. Webster. 2009. Carbon nanofibers and carbon nanotubes in regenerative medicine. Adv Drug Deliv Rev 61:1097-1114. DOI: 10.1016/j.addr.2009.07.010.

Ueno, T., S. Toyooka, T. Fukazawa, T. Kubo, J. Soh, H. Asano, T. Muraoka, N. Tanaka, Y. Maki, K. Shien, M. Furukawa, M. Sakaguchi, H. Yamamoto, K. Tsukuda, and S. Miyoshi. 2014. Preclinical evaluation of microRNA-34b/c delivery for malignant pleural mesothelioma. Acta Med Okayama 68:23-26.

Upadhyayula, V. K., S. Deng, M. C. Mitchell, and G. B. Smith. 2009. Application of carbon nanotube technology for removal of contaminants in drinking water: a review. Sci Total Environ 408:1-13. DOI: 10.1016/j.scitotenv.2009.09.027.

Vahedi, V, and P Pasbakhsh. 2015. Applications of natural mineral nanotubes in nanocomposites. In Natural mineral nanotubes. Properties and applications, edited by P. Pooria Pasbakhsh and P. G. Jock Churchamn. Oakville, ON L6L 0A2 , Canada; Wareton, NJ 08758, USA: Apple Academic Press Inc.

van der Bij, S., H. Koffijberg, V. Lenters, L. Portengen, K. G. Moons, D. Heederik, and R. C. Vermeulen. 2013. Lung cancer risk at low cumulative asbestos exposure: meta-regression of the exposure-response relationship. Cancer Causes Control 24:1-12. DOI: 10.1007/s10552-012-0107-7. 
Vandermeers, F., S. Neelature Sriramareddy, C. Costa, R. Hubaux, J. P. Cosse, and L. Willems. 2013. The role of epigenetics in malignant pleural mesothelioma. Lung Cancer 81:311318. DOI: 10.1016/j.lungcan.2013.05.014.

Wagner, J.C., C.A. Sleggs, and P. Marchand. 1960. Diffuse pleural mesothelioma and asbestos exposure in the North Western Cape Province. Br J Ind Med 17:260-271.

Xio, S., D. Li, J. Vijg, D. J. Sugarbaker, J. M. Corson, and J. A. Fletcher. 1995. Codeletion of p15 and p16 in primary malignant mesothelioma. Oncogene 11:511-515.

Xu, J., Y. Kadariya, M. Cheung, J. Pei, J. Talarchek, E. Sementino, Y. Tan, C. W. Menges, K. Q. Cai, S. Litwin, H. Peng, J. Karar, F. J. Rauscher, and J. R. Testa. 2014. Germline mutation of Bap1 accelerates development of asbestos-induced malignant mesothelioma. Cancer Res 74:4388-4397. DOI: 10.1158/0008-5472.CAN-14-1328.

Yoshikawa, Y., A. Sato, T. Tsujimura, M. Emi, T. Morinaga, K. Fukuoka, S. Yamada, A. Murakami, N. Kondo, S. Matsumoto, Y. Okumura, F. Tanaka, S. Hasegawa, T. Nakano, and T. Hashimoto-Tamaoki. 2012. Frequent inactivation of the BAP1 gene in epithelioidtype malignant mesothelioma. Cancer Sci 103:868-874. DOI: $10.1111 / \mathrm{j} .1349-$ 7006.2012.02223.x.

Zalcman, G., J. Mazieres, J. Margery, L. Greillier, C. Audigier-Valette, D. Moro-Sibilot, O. Molinier, R. Corre, I. Monnet, V. Gounant, F. Riviere, H. Janicot, R. Gervais, C. Locher, B. Milleron, Q. Tran, M. P. Lebitasy, F. Morin, C. Creveuil, J. J. Parienti, A. Scherpereel, and Intergroup French Cooperative Thoracic. 2015. Bevacizumab for newly diagnosed pleural mesothelioma in the Mesothelioma Avastin Cisplatin Pemetrexed Study (MAPS): a randomised, controlled, open-label, phase 3 trial. Lancet. DOI: 10.1016/S01406736(15)01238-6.

Zauderer, M. G., M. Bott, R. McMillan, C. S. Sima, V. Rusch, L. M. Krug, and M. Ladanyi. 2013. Clinical characteristics of patients with malignant pleural mesothelioma harboring somatic BAP1 mutations. $J$ Thorac Oncol 8:1430-1433. DOI: 10.1097/JTO.0b013e31829e7ef9. 